\title{
LAS LIBERTADES PÚBLICAS EN LA CONSTITUCIÓN DE 1869
}

\author{
JOSÉ ANTONIO SOUTO PAZ \\ Catedrático de Derecho Eclesiástico del Estado \\ Universidad Complutense de Madrid
}




\section{SUMARIO}

I. El LIBERALISMO ESPAÑOL Y LAS LIBERTADES PúblicAS. 1. El liberalismo originario: soberanía nacional y libertades individuales. 2. Doctrina y praxis del liberalismo español. II. LAS LIBERTADES PÚBLICAS EN EL PROCESO CONSTITUYENTE DE 1869. 1. El espíritu de la Revolución del 68 y la recuperación de las libertades públicas. 2. Las libertades públicas en el debate de las Cortes Constituyentes. III. EL CATÁLOGO DE LIBERTADES EN LA CONSTITUCIÓN DE 1869. 1. Una declaración sin precedentes en el constitucionalismo español. 2. Libertades de la persona física. Libertad y seguridad. 2.1. Inviolabilidad personal. 2.2. Inviolabilidad del domicilio. 2.3. Inviolabilidad de la correspondencia. 2.4. Garantías jurisdiccionales comunes. 3. Libertades del espíritu. 3.1. El mundo de las ideas y creencias: interpretación jurídica. 3.2. La libertad de pensamiento y su proyección a través de otras libertades instrumentales. 3.3. La libertad religiosa. 4. Libertades políticas y civiles. 4.1. El sufragio universal. 4.2. La libertad de acceso a los empleos y cargos públicos. 4.3. La libertad de empresa y de profesión. 4.4. La libertad de enseñanza. 5. Un numerus apertus de libertades públicas. 


\title{
LAS LIBERTADES PÚBLICAS EN LA CONSTITUCIÓN DE 1869
}

\author{
POR \\ JOSÉ ANTONIO SOUTO PAZ \\ Catedrático de Derecho Eclesiástico del Estado \\ Universidad Complutense de Madrid

\section{EL LIBERALISMO ESPAÑOL Y LAS LIBERTADES PÚBLICAS}

1. El liberalismo originario: soberanía nacional y libertades individuales

La Constitución de 1869 refleja el momento estelar del liberalismo español. Su presencia inaugural en las Cortes de Cádiz y su huella en la Constitución doceañista, fue borrada por la actitud reaccionaria del absolutista Fernando VII. Las conjuras habían comenzado en el propio proceso constituyente 1 , pero no impidieron la proclamación de un nuevo período histórico donde la soberanía nacional y la libertad parecian haber encontrado el puesto que le correspondía en la organización política española.

La soberanía radica en la nación y no en la familia real. Este principio, explícito en la Constitución del 12, permite entender que cuando «Napoleón, para usurpar el trono de España, intentó establecer como principio incontrastable, que la nación era una propiedad de la

1 Para una descripción detallada de estos sucesos vid. Argüelles, A., La reforma constitucional de Cádiz. Estudio, notas y comentarios de texto de J. Longares, Madrid, 1970, págs. 258 y ss. 
familia real, y bajo tan absurda suposición arrancó en Bayona las cesiones de padres e hijos, V. M. no tuvo otra razón para proclamar solemnemente en su augusto decreto de 24 de septiembre la soberanía nacional y dejar nulas las renuncias hechas en aquella ciudad de la Corona de España por falta de consentimiento libre y espontáneo de la nación, sino recordar a ésta que una de sus primeras obligaciones debe ser en todos tiempos la resistencia a la usurpación de su libertad e independencia ${ }^{2}$. Esta doctrina va a quedar reflejada en los primeros artículos de la Constitución, al señalar que la «nación española es la reunión de todos los españoles» (art. 1), "es libre e independiente, y no es, ni puede ser, patrimonio de ninguna familia ni persona" (art. 2). Definida así la nación, se la reconoce como titular de la soberanía: «la soberanía reside esencialmente en la Nación, y por lo mismo pertenece a ésta exclusivamente el derecho a establecer sus leyes fundamentales" (art. 3).

La proclamación de la soberanía nacional, realizada en estos términos, podría interpretarse como una manifestación española del espíritu ilustrado, que había inspirado la Revolución francesa y que se había plasmado en la Declaración de Derechos del Hombre y del Ciudadano de 1789, al decir que: «El origen de toda soberanía reside esencialmente en la nación. Ningún órgano ni ningún individuo puede ejercer autoridad que no emane expresamente de ella" (art. $3 .^{\circ}$ ) y ratificado en la Constitución de 1791, que dispone lo siguiente: "La soberanía es una, indivisible, inalienable e imprescriptible. Pertenece a la Nación; ninguna sección del pueblo ni ningún individuo puede atribuirse su ejercicio" (Título III, art. 1). No cabe la menor duda que estas declaraciones constituyen el fundamento de los poderes de la Asamblea Nacional, autora tanto de la Declaración como de la Constitución, que ponen fin al absolutismo político en Francia. $Y$ no puede olvidarse la influencia doctrinal del Abate Sieyés en la fundamentación de esta doctrina en su conocido manifiesto: "¿Qué es el Estado llano?»3.

2 Argüelles, A., Discurso preliminar a la Constitución de 1812, Ed. Centro de Estudios Constitucionales, Madrid, 1981, págs. 78-79.

3 SIEYĖs, E.-J., ¿Qué es el Estado llano?, Ed. Centro de Estudios Constitucionales, 1988. Sobre la influencia del liberalismo en la evolución del constitucionalismo, v. MATEuccl, N., Historia del constitucionalismo moderno. Organización del poder y libertad, trad. esp., Madrid, 1988. Una recopilación de los textos más significativos del constitucionalismo moderno se encuentra en Textos básicos de la Historia Constitucional Comparada, ed. de Varela Suanzes, J., Centro de Estudios Constitucionales, Madrid, 1998. 
La presencia de un buen número de diputados ilustrados en las Cortes gaditanas podria avalar esa interpretación, así como la influencia de los postulados de los documentos de la Revolución Francesa en la Constitución de 1812. Sin embargo, y tal vez como consecuencia de las circunstancias histórico-políticas y del clima hostil hacia los Ilamados "afrancesados", se advierte, desde el primer momento, el intento de distanciarse de los acontecimientos revolucionarios franceses, buscando las raíces de la soberanía nacional y de las libertades en nuestro derecho tradicional.

Es necesario citar de nuevo a Argüelles y su Discurso Preliminar, pues, desde el primer momento de su exposición, pretende alejar cualquier influencia francesa y remitir el fundamento del nuevo orden constitucional a la tradición jurídica española: "Nada ofrece la Comisión en su proyecto que no se halle consignado del modo más auténtico y solemne en los diferentes cuerpos de la legislación española, sino que se mira como nuevo el método con que se han distribuido las materias, ordenándolos y clasificándolos para que formasen un sistema de ley fundamental y constitutiva en el que estuviese contenido con enlace, armonía y concordancia cuanto tienen dispuesto las leyes fundamentales de Aragón, de Navarra y de Castilla en todo lo concerniente a la libertad e independencia de la nación, a los fueros y obligaciones de los ciudadanos, a la dignidad y autoridad del Rey y de los tribunales, al establecimiento y uso de la fuerza armada y método económico y administrativo de las provincias» ${ }^{4}$.

Alejarse de la influencia revolucionaria francesa, así como de las ideas filosóficas que le sirvieron de soporte, pareció una actitud generalizada que permitía poner fin al absolutismo político y reconocer los derechos y libertades de los ciudadanos, sin caer en la animadversión

4 Argüelles, A., Discurso preliminar..., cit., págs. 67 y 68. Para Artola, M., este texto es el mejor ejemplo de la uintención mixtificadora de la referencias históricas de Argüelles, "en el que se ha buscado una defensa de la tradición frente a la revolución». Y, para confirmar este aserto, añade: «Para legitimar las novedades políticas, el autor del Discurso acude a proposiciones que toma de textos de cualquier tiempo pasado, sin preocuparse de los cambios producidos en el intervalo de varios siglos. La elección de los reyes godos se toma cómo argumento para probar la soberanía nacional. La soberanía de la Nación está reconocida y proclamada en las leyes fundamentales de este Código (Fuero Juzgo). Al servicio de la causa revolucionaria, los liberales crearon un pasado de libertades, que alimentó la historiografia durante un siglo» («Estudio Preliminar», en A. dE ARGÜELLES, Examen Histórico de la Reforma Constitucional de España, Tomo l, Junta General del Principado de Asturias, 1999, pág. LXXII). 
que, en muchos sectores, provocaban las ideas revolucionarias y las doctrinas filosóficas ilustradas 5 .

La fundamentación del nuevo orden constitucional en la tradición política española pretende alejarlo, tanto del fenómeno revolucionario francés como del absolutismo político, auténtica desviación y corrupción de nuestras tradiciones históricas. Así lo refleja uno de los más brillantes historiadores del derecho español del siglo XIX, Martínez Marina, quien, de manera rotunda, manifiesta que: "el pacto social no es obra de la filosofía ni invención del ingenio humano, es tan antiguo como el mundo, la sociedad civil es efecto de un convenio, estriba en un contrato del mismo modo que la sociedad conyugal o la sociedad doméstica. No me permite la naturaleza de este escrito

5 MARTínez MARINA, F., reflejará con precisión este ambiente al manifestar: "Bien conozco que muchos Españoles privados de las luces de la conveniente educación que todo gobierno justo debe proporcionar a los que nacen y se crían para ser útiles ciudadanos, sumidos en las más profunda ignorancia de la sociabilidad $y$ de los derechos del hombre, imbuidos desde la niñez en máximas destructoras que asi se encaminan a abolir las primeras ideas de libertad como a fortificar la opinión de la soberania y absoluta autoridad de los Reyes, y a difundir el dogma de una ciega y pasiva obediencia, y la indispensable necesidad de sufrir en silencio el yugo de la tirania; habituados a estos objetos, ideas y máximas consagradas por el uso de toda la vida, y a no oír sino los ecos de la más vil y supersticiosa adulación, se escandalizan sólo con el nombre de pactos, convenios, tratados, derechos del pueblo, libertad, leyes fundamentales, obligaciones y responsabilidades de las minorías. Los agentes del despotismo hicieron los mayores esfuerzos para desacreditar esa doctrina y que recayese sobre ella toda la odiosidad de su ponzoñoso origen, el cual según dicen no pudo ser otro que la razón desvariada y que la moderna e irreligiosa filosofía" (Discurso sobre el origen de la monarquía y sobre la naturaleza del Gobierno español, Ed. Centro de Estudios Constitucionales, Madrid, 1988, pág. 102). Sobre el pensamiento de MARTínez MARINA, v. Varela Suanzes, J., Tradición y liberalismo en Martínez Marina, Oviedo, 1983. Por su parte, Fernández Almagro, M., califica a los diputados gaditanos, en relación con los constituyentes franceses, como «menos revolucionarios" y "más penetrados de tradición y ley" (Orígenes del régimen constitucional en España, Barcelona, 1976, pág. 133). Sobre los origenes de esta declaración y la posible influencia de las declaraciones de derechos americanas, v. Jellinek, J., La Declaración de Derechos del Hombre y del Ciudadano. Estudio de Historia Constitucional Moderna, trad. española de A. Posada, Madrid, 1908. Sobre la problemática histórica de estos derechos desde una perspectiva actual, v. FIORAVANTI, M., Los derechos fundamentales. Apuntes de Historia de las Constituciones, trad. esp., Madrid, 1996. Un estudio de los derechos fundamentales en los siglos precedentes al XIX se encuentra en Historia de los Derechos Fundamentales. Tomo I: "Tránsito a la modernidad. Siglos XVI y XVII".. Dirección: PeCes-Barba Martínez, G., y Fernández Garcia, E., Madrid, 1998; Tomo Il: Siglo XVIII, 3 vols. Dirección: PeCES-BARBA, G.; FernÁNDEZ GARCla, E., y Asis Roig, R. de, Madrid, 2001. 
recoger las pruebas y documentos que demuestran la verdad de este axioma político; más todavía no omitiré el testimonio de un gran hombre y cuya autoridad a nadie puede ser sospechosa, la del príncipe de los teólogos escolásticos, Santo Tomás de Aquino, el cual en la Edad Media, época muy remota de la del nacimiento de la nueva filosofía y como quinientos años antes que el ciudadano de Ginebra publicase su célebre obra, establece el contrato social como el fundamento de la sociedad política, le da tanta fuerza que no duda asegurar que si el Príncipe abusase tiránicamente de la potestad regia y quebrantare el pacto, pudiera el pueblo aun cuando se le hubiese antes sometido perpetuamente, refrenar y aun destruir su autoridad, disolver el gobierno y crear otro nuevo por la manera que lo hicieron los romanos cuando arrojando a Tarquino del trono proscribieron la monarquía y crearon el gobierno consular o la repúblican 6 .

Las referencias al derecho histórico, como fundamento de la nueva Constitución, $y$ "el pasado de libertades" que invocan los constituyentes gaditanos, en palabras de Artola, no excluyen las coincidencias básicas entre los planteamientos revolucionarios franceses y las bases de la nueva organización política española: "La soberanía no reside en el Rey, como ocurría en el absolutismo político, sino en la nación, es decir, en él pueblo" ${ }^{7}$. La asociación del pueblo, convertido en nación, tiene como meta "la conservación de los derechos naturales e imprescriptibles del hombre. Estos derechos son la libertad, la propiedad, la seguridad y la resistencia de la opresión " 8 , una declaración que coincide sustancialmente con la contenida en la Constitución de 1812: "La Nación está obligada a conservar y proteger por leyes sabias y justas la libertad civil, la propiedad, y los demás derechos legítimos de todos individuos que la componen ${ }^{9}$.

El liberalismo ha puesto sobre la mesa una cuestión crucial de la ciencia política: la ecuación poder-libertad. Más allá de las raíces doctrinales o de los nuevos postulados políticos, la cuestión radica en la formulación, interpretación y aplicación de esta ecuación, que permitirá identificar si la libertad individual y colectiva es el fundamento del orden político o, simplemente, una concesión del poder, que puede reconocerla, limitarla o suprimirla, sin quebrantar el orden político establecido. Esta es la historia del siglo XIX y, en concreto, del libera-

\footnotetext{
lbidem, pág. 102.

lbidem, pág. 103.

La Declaración de Derechos del Hombre..., cit., art. 2.

Art. 4.
} 
ralismo político, que no alcanzará sus objetivos políticos plenos hasta la Constitución de 1869, aunque este logro fuera ciertamente efímero.

\section{Doctrina y praxis del liberalismo español}

No cabe la menor duda que el objetivo político primario del liberalismo es la devolución a los ciudadanos de la libertad política y de las libertades civiles, lo que exige la subordinación del poder a estos principios y el establecimiento de los límites necesarios para que el poder no invada las esferas reservadas a la autonomía individual y colectiva. Sin embargo, la historia constitucional española nos deparará más de una sorpresa a la hora de reflejar normativamente los objetivos antes señalados. No me refiero, por supuesto, a la actitud arbitraria y absolutista de Fernando VII, aboliendo la Constitución de 1812. Me refiero a los propios textos elaborados por los liberales que ponen en entredicho las declaraciones de principios que presiden su programa político.

Ya en la Constitución de 1812, después de la solemne declaración de que la soberanía reside en la nación, observamos que la potestad legislativa es compartida por las Cortes y el Rey, mientras que la potestad ejecutiva es adjudicada en exclusiva al propio Rey ${ }^{10}$.La presencia regia y la asunción de poderes se hace más notoria y decisiva en el Estatuto Real de 1834, siendo ratificada en las Constituciones de $1837^{11}$ y $1845^{12}$. Y ¿dónde han quedado las libertades? Sin hacer un elenco claro de los derechos y libertades de los españoles, éstos aparecen dispersos en capítulos varios, garantizando la libertad individual ${ }^{13}$, la inviolabilidad del domicilio ${ }^{14}$, así como la libertad de escribir, imprimir y publicar sus ideas políticas ${ }^{15}$. Es común al reconocimiento de estos derechos y libertades la carencia de garantías jurídicas, que impidan al gobierno suspender o destituir a los ciudadanos del ejercicio de estos derechos ${ }^{16}$. A todo ello hay que

10 Artículos 15 y 16.

11 Artículos $12,45,46$ y 47.

12 Artículos $12,43,44,45$ y 46.

13 Artículos 287 y ss. de la Constitución de 1812 ; también arts. 7 y 8,9 y 10 de 1837 y 1845.

14 Art. 306, ibidem.

15 Ibidem, art. 371; también art. 2 Constitución de 1837 y de 1845.

16 Son significativos al respecto los artículos $2,7,8$ y 10 de la Constitución de 1837 y los artículos 6, 7 y 8 de la Constitución de 1845. 
añadir la ausencia total del reconocimiento del derecho de libertad religiosa y la conservación de la confesionalidad del Estado, convirtiendo a la religión católica en principio político fundamental del Reino ${ }^{17}$. ¿Es compatible este principio con la declaración de la Constitución de 1812 de que ula Nación está obligada a conservar y proteger por leyes sabias y justas la libertad civil, la propiedad, y los demás derechos legítimos de todos los individuos que la componen" (art. 4)? Curiosamente esta cláusula garantista de las libertades individuales desaparecerá en los sucesivos textos de rango constitucional: Estatuto Real (1834) y Constituciones de 1837, 1845 y 1856.

La evolución del constitucionalismo español ${ }^{18}$, siguiendo las tendencias extranjeras, caminará por la vía del fortalecimiento de la sobe-

17 La confesionalidad católica del Estado español se mantuvo con variaciones gramaticales a lo largo de todo el constitucionalismo decimonónico. La Constitución de 1812 declara, al respecto, que: "La Religión de la nación española es y será perpetuamente la católica, apostólica, romana, la única verdadera. La Nación la protege por leyes sabias y justas y prohíbe el ejercicio de cualquiera otran. En su discurso Preliminar Argüelles se limita a decir: "La declaración solemne y auténtica de que la religión católica, apostólica, romana es y será siempre la religión de la nación española, con exclusión de cualquiera otra, ha debido ocupar en la ley fundamental del Estado un lugar preeminente, cual corresponde a la grándeza y sublimidad del objeto» (pág. 80). Años más tarde, sin embargo, admitiría que: "En el punto de la religión se cometía un error grave, funesto, origen de grandes males, pero inevitable. Se consagraba de nuevo la intolerancia religiosa, y lo peor era que, por decirlo asi, a sabiendas de muchos, que aprobaron con el más profundo dolor el artículo 12. Para establecer la doctrina contraria hubiera sido necesario luchar frente a frente con toda la violencia y furia teológica del clero, cuyos efectos demasiado experimentados estaban ya, asi dentro como fuera de las Cortes. Por eso se creyó prudente dejar al tiempo, al progreso de las luces, a la ilustrada controversia de los escritores, a las reformas sucesivas y graduales de las Cortes venideras, que se consiguiese, sin lucha ni escándalo, el espíritu intolerante que predominaba en una gran parte del estado eclesiástico. Los que se abstuvieron entonces hasta de contradecir los indiscretos términos de aquel artículo, lo hicieron en obsequio de la paz y armonía que sinceramente deseaban conservar con un clero ingrato, incapaz no sólo de corresponder, pero ni de conocer siquiera hasta dónde subía de precio el sacrificio de la propia reputación para çon el mundo ilustrado; de un clero que retribuyó esta generosa condescendencia, esta conducta tan fraternal y patriótica, con una persecución inaudita y cruel contra los que la defendieron y honraron, y no menos ignominiosa y funesta para la nación, a quien robó después toda la gloria y utilidad del triunfo que se había conseguido" (La reforma..., cit., págs. 262-262).

18 Sobre esta cuestión, v. SÁnCHEz Agesta, L., Historia del constitucionalismo español, 2." ed., Madrid, 1964; FARÍAs, P., Breve historia constitucional de España, Madrid, 1975; ToMÁs VILlarRoYA, J., Breve Historia del Constitucionalismo español, Madrid, 12. ${ }^{\circ}$ ed., 1997; FERnÁndez SEGADO, F., Las Constituciones históricas españolas, Madrid, 1992; Solé TuRA Y AJA, E., Constituciones y períodos constituyentes en España (1808-1936), Madrid, 1977, así como los diferentes estudios 
ranía real, con detrimento de la soberanía nacional, y con una concepción restringida de las libertades, entendida como una concesión por parte del poder y limitada a los supuestos concretos reconocidos normativamente, exenta de garantías jurídicas $y$, por tanto, susceptible de ser limitada o suspendida de manera preventiva por el poder ejecutivo. Este cambio progresivo se advierte en la argumentación del Gobierno moderado de 1856, al señalar que se ha de elegir, entre las diferentes fórmulas de organización constitucional practicadas en España, aquella que satisfaga más cumplidamente los deseos legítimos de los pueblos, optando por aquello que, "tributando un justo homenaje al principio inconcuso de libertad no incurra en la preocupación, que afortunadamente se va ya anticuando, de considerarle como el objeto único y supremo del Estadon" ${ }^{19}$; por ello, declara que "la Constitución promulgada en Cádiz el 19 de marzo de 1912 no llena estas condiciones, ni se adapta al estado político-social de la Monarquía Española, es una tesis elevada ya a la categoría de las verdades más triviales. Sus mismos ilustres autores lo reconocieron lealmente así, cuando calmado el fervor de los primeros ímpetus $y$ amaestrados por extraños y propios escarmientos, contemplaron a la luz de la experiencia y de los adelantos de la política la impracticabilidad y esterilidad de aquellas máximas, cuyo falso brillo los había primero deslumbrado" ${ }^{20}$.

El Gobierno impide así la aprobación de la Constitución de 1856, que pretendía ampliar la declaración de derechos, limitar el poder real y democratizar la composición de las Cortes. "Su base política se encuentra en el carácter absoluto que recibe el concepto de soberanía nacional del artículo $1 .^{\circ}$ : todas las instituciones $-y$ por tanto la propia

de J. DE Esteban, entre otros, Las Constituciones de España, Madrid, 1998, y Torres DEL MORAL, A., Constitucionalismo histórico español, Madrid, 1999. También, ÁlvaREZ CONDE, E., Curso de Derecho Constitucional, vol. 1, 3. ${ }^{a}$ ed., Madrid, 1999, págs. 66 y ss.

19 Real Decreto de 15 de septiembre de 1856 restableciendo la Constitución promulgada en 23 de mayo de 1845, edición de Raquel Rico Linaje, Universidad de Sevilla, Sevilla, 1989, págs. 128.

20 Ibidem. Este argumento corrobora la postura de TORRES DEL MORAL, que llama la atención sobre la usuperficialidad del constitucionalismo español» y que concreta en el hecho de que "cuando cambiaba el grupo en el poder, se modificaban dichos objetivos, o alguno de ellos, y se sentía la imperiosa necesidad de cambiar la Constitución. Pero, como las estructuras sociales y económicas y la cultura política no podian transformarse automáticamente, la nueva Constitución era indefectiblemente falseada en su aplicación, lo mismo que lo había sido la anterior y habría de serlo la siguiente" (Constitucionalismo histórico..., cit., págs. 16-17). 
Corona- deben su existencia a la voluntad de la nación ${ }^{21}$. La suspensión del procedimiento de aprobación de esta Constitución significa la muerte del espíritu de Cádiz y, en concreto, de los dos principios en que descansaba la primera constitución española: la soberanía nacional y las libertades individuales de los españoles. La proclamación de la soberanía nacional 22 y el reconocimiento de los derechos y libertades individuales ${ }^{23}$, que transcienden el mero marco programático para convertirse en normas vinculantes para los poderes públicos y todos los miembros integrantes de la nación ${ }^{24}$, son rechazados por el Gobierno moderado, que sostiene la "impracticabilidad y esterilidad" de estos principios y la necesidad de relegarlos a un segundo plano.

Este proceso político requiere una explicación. Es preciso recordar que el adversario político del liberalismo originario, el gran obstáculo para llevar a cabo sus programas y objetivos políticos, fue el absolutismo político, representado en la figura de Fernando VII, que abolió, impidió $y$, en su caso, destruyó las reformas liberales. Pero, a partir de 1834, el liberalismo estará presente en la vida política española, ejerciendo el poder de manera continuada hasta 1868. ¿Qué ha impedido, desde entonces, la puesta en práctica de los principios del liberalismo originario?

Las tensiones y retrocesos operados en la vida política durante este período se deben, principalmente, a la escisión de los liberales, que aparecerán encuadrados en dos movimientos políticos distintos y enfrentados: moderados y progresistas. Mientras estos últimos pretender conservar y llevar a la práctica el "espíritu doceañista", los moderados van a adoptar una postura más acomodaticia, inspirándose en los "doctrinarios» franceses ${ }^{25} y$ dando lugar a lo que se ha

21 Solé Tura y AJa, E., Constituciones y periodos constituyentes en España (1808-1936), Madrid, 1977, pág. 50.

22 Artículos 1, 2 y 3 de la Constitución de 1812.

23 Artículo 4 de la Constitución de 1812.

24 Romero Moreno, J. M., Procesos y derechos fundamentales en la España del siglo XIX, Ed. Centro de Estudios Constitucionales, 1983, págs. 70 y ss.

25 «El eclecticismo en filosofía, combatiendo la doctrina de la sensación, proclama la actitud libre del espíritu humano, dando la principal importancia a la observación completa de todos los fenómenos de la inteligencia del hombre; y reduce, asi puede decirse, la filosofia a la psicologia. Y este sistema no tiene criterio filosófico, propio o especial suyo, a no ser que se considere que lo es el espiritu de conciliación, que le hace acoger todos los sistemas desfigurándolos; y así en último resultado, desnaturaliza y debilita el sentimiento del deber del hombre, en medio de esta confusión y verdadera anarquía de confusión de ideas. Pues bien; la escuela doctrinaria, conforme con estos principios filosóficos y esta filosofía 


\section{denominado liberalismo doctrinario ${ }^{26}$.}

Aunque, inicialmente, el partido moderado expresa, más que un contenido una negación: «los que al nuevo partido pertenecen esfuérzanse sencillamente por oponerse a las tendencias políticas extremas que con sus radicalismos trataban de dominar la vida política del país. Con el tiempo irá concretándose el cuerpo de ideas del partido moderado, pero siempre este vocablo tendrá un sentido amplio e impreciso" ${ }^{27}$. Sin embargo, "la doctrina que el partido moderado presentaba como nueva estaba muy lejos de ser una especie de descubrimiento de la piedra filosofal; conocian perfectamente la escuela maravillosa todos los que habían saludado a los autores doctrinarios de Francia» 28 .

Hay en el partido moderado dos premisas claras: a) el alejamiento de los principios políticos que inspiraron las Cortes de Cádiz, y b) el relativismo político, que excluye cualquier sujeción de la praxis políticas a principios doctrinales más o menos rígidos. Como recuerda Díez del Corral, "frente a la abstracta postura doceañista que desarrollaba ciegamente los principios sin medir las consecuencias, se proclama por Martínez de la Rosa que en materia de legislación y de

negativa y estéril y con una metafísica de transacciones, mezcla de sabios reaccionarios y de recuerdos gubernamentales; desechando el derecho divino de los reyes y la soberanía nacional, proclama la soberanía de la inteligencia o de la razón; y considera la Monarquía Constitucional, sobre la base de un gobierno democrático, como la mejor y la forma definitiva de la libertad.

Y esta doctrina política que se propuso, colocándose entre el Antiguo Régimen y la revolución, combinar la Monarquía y la libertad, tomando en la apariencia algunas prácticas parlamentarias de la Monarquia inglesa, ha confundido, con una imparcialidad puede decirse escéptica, el pasado y el presente, el bien y el mal políticos, con la exclusiva mira de la seguridad del gobierno o del poder y un sentimiento egoísta de conservación. Y si el mandaje metafísico de la legitimidad y de la libertad sobre cierto pie de igualdad, produce por algún tiempo el reposo; bien pronto esas circunstancias, que se quieren amalgamar a titulo de un derecho igual se miran siempre como enemigos y se hallan dispuestas a combatir, logrando sólo establecer una lucha constante entre las dos y se puede decir que una revolución latente en la sociedad. Esta política, ten celosa únicamente para el bien personal de unos pocos e indiferente en cuanto a los medios de conseguirlo, afecta ser sobre todo gubernamental y parece hábilmente conservadora de todo poder existente, consistiendo solamente en teoría la resistencia legal, pero condenando después todo movimiento revolucionario" (Serrano, L. J., Estudios sobre el Régimen Constitucional y su aplicación en España, cap. VI: “De la Escuela doctrinaria», Madrid, 1876, págs. 66 y 67).

26 DIEZ DEL CORRAL, L., El liberalismo doctrinario, Ed. Centro de Estudios Constitucionales, Madrid, 1984.

27 Diez del Corral, L., op. cit., pág. 525.

28 FERNÁNDEZ DE LOS RIOS, A., Estudio histórico de las luchas políticas de España del siglo XIX, 2. ed., Madrid, 1879, I, pág. 230. 
gobierno no hay principio cierto que llevado hasta sus últimas consecuencias no incurra en el absurdo" 29.

El Estatuto Real constituye el documento más expresivo de la síntesis ideológica del liberalismo doctrinario y de lo que iba a ser el perfil político del futuro partido moderado. «El Estatuto Real -añade Díez del Corral - es sólo el primer paso, corto y precavido, una especie de Constitución, como decía Burgos, que sólo había echado los cimientos, sobre los que se debía seguir levantando el edificio del régimen. Pero tales ideas y tales esperanzas no eran suficientes para calmar los anhelos de la opinión liberal, sin que la intención moderada que tuvieran acertase a congraciarse al sector de ideas tradicionalista. Al poco tiempo de su promulgación es patente que el Estatuto Real no ofrece bases sólidas para la organización política del país. Su ampliación, principalmente en lo relativo a derechos individuales, es reclamada no sólo por los liberales exaltados, sino por sectores políticos que luego formarán en el partido moderado ${ }^{30}$.

El eclecticismo doctrinario y la renuncia a los principios políticos del liberalismo originario queda reflejada en la figura eminente del moderado Alcalá Galiano, quien refiriéndose a los principios decía: "Puros no cabe duda que son dañinos por demás, y así lo importante es descubrir cuál es el diluente en que deben perder su violencia nociva, el principio contrario que ha de templarlos, y la cantidad así como la calidad de fuerza necesaria a contrarrestar la suya hasta convertirla de destructora en saludable ${ }^{31}$. No podía faltar quien ante esta actitud tan combativa respondiera con estas palabras: "Un día - diría Quiret, que se encontraba entre el auditorio - anulaba el principio de soberanía, otro el de la igualdad, otro el del sufragio ${ }^{32}$.

La historia constitucional y la actuación de los sucesivos gobiernos moderados revelan el alejamiento de los principios liberales de las Cortes de Cádiz y explican la frustración de los liberales progresistas. Al margen de los hechos concretos que provocaron la Revolución de 1868 , hay un dato evidente, que va a estar presente en el sexenio revolucionario: la pretensión de hacer realidad las aspiraciones liberales y la vigencia real y efectiva de las libertades públicas.

29 Op. cit., pág. 511.

$30 \quad$ Ibidem, pág. 522.

31 Alcala Galiano, A., Lecciones de Derecho Político Constitucional, Madrid, 1843, pág. 226.

32 Diez del CORRAL, L., op. cit., pág. 544. 


\section{LAS LIBERTADES PÚBLICAS EN EL PROCESO CONSTITUYENTE DE 1869}

\section{El espíritu de la Revolución del 68 y la recuperación de las libertades públicas}

Cádiz vuelve a ser protagonista de la lucha por las libertades, al convertirse en la ciudad donde se inicia la Revolución de 186833. "Desde estas murallas, siempre fieles a nuestra libertad e independencia"s se publica el Manifiesto "España con honra", el 19 de septiembre de $1868^{34}$. La recuperación de las libertades, proclamadas en las Cortes Constituyentes de Cádiz, y de la soberanía nacional, pervertidas ambas por los gobiernos "moderados», vuelven a tener su punto de partida en la ciudad de Cádiz, siendo recogidas fielmente por la Junta Provisional, creada en Madrid, a través de su Manifiesto de 30 de septiembre de 1868, y por el Gobierno provisional en su Manifiesto de 25 de octubre de $1868^{35}$.

La Junta Revolucionaria de Madrid, en su Manifiesto dirigido a las Juntas Revolucionarias provinciales, comenzará este documento con las siguientes palabras: "El pueblo de Madrid acaba de dar el grito santo de libertad y abajo los Borbones" y lo concluirá con estos

33 Una visión temática plural de la Revolución del 68 puede verse en La Revolución de 1868. Historia, Pensamiento, Literatura. Selección de C. E. LIDA e I. M. Zavala, Prólogo de Vicente Llorens (ed.), Las Americas Publishing Company, New York, Madrid, 1970.

34 En el Manifiesto se describen las causas de la Revolución que, entre otras, se centran en las siguientes: "Hallada la Ley Fundamental, convertida siempre antes en celada que en defensa del ciudadano; corrompido el sufragio por la amenaza y el soborno, dependiente la seguridad individual, no del derecho propio, sino de la irresponsable voluntad de cualquiera de las autoridades; muerto el municipio; pasto la Administración y la Hacienda de la inmoralidad y del agio; tiranizada la enseñanza; muda la prensa y sólo interrumpido el universal silencio por las frecuentes noticias de las nuevas fortunas improvisadas, del nuevo negocio, de la nueva real orden encaminada a defraudar el Tesoro Público; de títulos de CastiIla vilmente prodigados; del alto precio, en fin, a que logran su venta la deshonra y el vicio. Tal es la España de hoy...(Manifiesto "España con honra. Cádiz, 19 de septiembre de 1868", en Documentos de Historia Contemporánea de España, Ed. Actas, Madrid, 1996, págs. 219 y ss.).

35 Como dice F. FernÁndez SEgado: "Si analizamos las diferentes proclamas y manifiestos de las Juntas revolucionarias que proliferan por doquier, observaremos que en todas ellas subyace un objetivo político común: la necesidad de un cambio radical con el que se puedan garantizar las libertades individuales" (Las Constituciones históricas españolas, Madrid, 1992, pág. 274). 
otros: "¡Españoles!. Secundad todos el grito de la que fue Corte de los Borbones y de hoy más será el santuario de la Libertad» ${ }^{36}$.

Con estos antecedentes no puede extrañar que el Manifiesto del Gobierno Provisional sea un canto a la libertad y una descripción de las libertades especializadas que será necesario garantizar expresamente. El Gobierno provisional recuerda, como punto de partida para la promulgación de sus principios regeneracionistas, una circunstancia muy concreta: «...la revolución ha empezado por sentar un hecho que es la base robusta sobre la cual deben descansar sus reconquistadas libertades. Este hecho es el destronamiento y expulsión de una dinastía que, en abierta oposición con el espíritu del siglo, ha sido rémora a todo progreso, y sobre la cual el Gobierno provisional, por respeto a sí mismo, cree oportuno tender la conmiseración de su silencio....137.

La reconquista de las libertades exigía la remoción del obstáculo que había impedido su vigencia en España, al rechazar los principios de las Cortes Constituyentes de 1812. "Destruido el obstáculo (la dinastía borbónica) y expedito el camino, la revolución ha establecido el sufragio universal, como la expresión más evidente y palpable de la soberanía del pueblo" ${ }^{38}$. Se retoma así el espíritu de las Cortes liberales de Cádiz y de la Constitución de 1812, donde la soberanía reside en la nación y la nación es el pueblo, sin que sea compartida con el Monarca. La concesión realizada en nuestro primer texto constitucional, (plasmada en los artículos 168 y ss., y en aparente contradicción con lo dispuesto en los cuatro primeros, donde se establecen los principios básicos del nuevo régimen), de compartir la soberanía nacional entre la nación y el monarca, acabaría siendo la causa de la usurpación por esta última de la soberanía y, en consecuencia, de la sumisión de la Nación a la voluntad caprichosa y arbitraria de la Corona y de sus Gobiernos.

La recuperación de la soberanía nacional y la consiguiente titularidad exclusiva de la soberanía a favor de la nación se expresa, en la Constitución del 69, a través del reconocimiento del sufragio uni-

36 «La revolución en Madrid: la Junta Provisional (30 de septiembre de 1868)", en Documentos..., cit., págs. 200-202). Un estudio contemporáneo del reinado de Isabel II puede verse en MARQués DE Miraflores, Memorias del Reinado de Isabel II. Estudio preliminar y edición de M. Fernandez Álvarez, Madrid, 1964.

37 "Manifiesto del Gobierno Provisional (25 de octubre de 1868)", en Documentos..., cit., págs. 224 y ss.

38 lbidem. 
versal, que, por primera vez, se reconocerá como un derecho constitucional de todos los españoles. La consecuencia inmediata de la aplicación de este principio es la negación de cualquier titularidad de la soberania por parte de la Corona, excluyendo, incluso, el carácter compartido que había sido la coartada del liberalismo doctrinario, practicado por los moderados, y que había conducido al monopolio del ejercicio de la soberanía por parte de la Corona y sus gobiernos. Sobre esta base fundamental, "proclamados los principios sobre los cuales debe cimentarse nuestro futuro régimen gubernamental, basados en la libertad más amplia, y reconocido por todas las Juntas, nacidas al calor del programa de Cádiz, pasa el Gobierno provisional a compendiar en un solo cuerpo de doctrina estas manifestaciones del espíritu público distintamente expresadas, pero con la misma intensidad sentidas» ${ }^{39}$.

La libertad constituye el eje fundamental sobre el que gira la Revolución de 1868 y, por ello, el Manifiesto del Gobierno provisional la sitúa como piedra angular del nuevo sistema político, una vez que ha sido eliminado el obstáculo tradicional para su implantación definitiva, es decir, la expulsión de la dinastía borbónica. Esta declaración, sin embargo, peca de una cierta ingenuidad, si tenemos en cuenta los intereses de otros grupos que habían utilizado la Corona para la consecución de sus propios fines y para el beneficio de sus propios intereses ${ }^{40}$.

Movido por esta ingenuidad, que se refleja en la proclamación pura y diáfana de los principios liberales, el Gobierno provisional no se limita a reivindicar la libertad como eje central de la nueva política, sino que da un paso más adelante, y enumera aquéllas libertades especializadas, que es necesario consagrar como áreas de inmunidad personales y que el nuevo régimen deberá reconocer y garantizar expresamente. Sin temor a las consecuencias 0 , tal vez, fruto de esa ingenuidad, a la que antes nos referimos, el Manifiesto del Gobierno Provisional comienza la enumeración de las libertades especializadas, mencionando en primer lugar la libertad religiosa. Esta manifestación es absolutamente correcta, desde un punto de vista doctrinal y sistemático, puesto que se trata de la primera libertad especializada en el

39 Ibidem.

40 "....Los derechos pasaron a la Constitución con esa mínima regulación de la casuística constitucional, esperando que la fiebre remitiera según la ley de la naturaleza. Pero la fiebre fue en efecto tan alta - según Sánchez Agesta- que es tradición que un prohombre de aquellas Cortes, añadió a las expresiones sacramentales, naturales, absolutos, ilegislables, una expresión burlesca: los derechos inaguantables" (FERnÁNDEZ SEGADO, F., Las Constituciones históricas..., cit., pág. 284). 
plano cronológico y ontológico41. Desde el punto de vista de la praxis política, sin embargo, se trata de la libertad más combatida por amplios sectores sociales y políticos, que vinculan la unidad nacional a la unidad religiosa, centrada en el culto único y exclusivo de la religión católica.

El mantenimiento de este principio en la Constitución de 1812, con la consiguiente prohibición del derecho de libertad religiosa y la conservación de un régimen radical de intolerancia religiosa, calificado por el propio Argüelles - años más tarde-como un grave error, hicieron inútiles entonces el ejercicio de otras libertades, como la libertad de imprenta o la libertad de enseñanza, pues todas ellas estaban destinadas a entrar en colisión con una doctrina y una moral confesional, que impedía el ejercicio de cualquier ámbito de libertad que pudiera resultar contraria a las mismas.

La propuesta del Gobierno provisional de afrontar el reconocimiento del derecho de libertad religiosa refleja una actitud seria, racional y coherente, en relación con su compromiso de implantar las libertades públicas en el sistema político y jurídico español. Pero, al mismo tiempo, suponía crear un frente de oposición radical, encabezado por las fuerzas clericales y afines, que hacian de este debate una cuestión de Estado. El argumento del Gobierno provisional, correcto en el orden doctrinal y político, no evitará una reacción radical contra esta propuesta, a pesar de las buenas intenciones manifestadas por el Gobierno: «No se vulnerará - dice el Manifiesto gubernamental- la fe hondamente arraigada porque autoricemos el libre y tranquilo ejercicio de otros cultos en presencia del católico; antes bien se fortificará en el combate, y rechazará con el estímulo las tenaces invasiones de la indiferencia religiosa, que tanto postran y debilitan el sentimiento moral... ${ }^{42}$

Enunciada la libertad religiosa, como la primera de las libertades espirituales, el Manifiesto gubernamental pasa a enumerar otras libertades que son, simplemente, consecuencias necesarias de la primera: la libertad de enseñanza, la libertad de imprenta, las libertades de reunión y asociación, etc. "La libertad de enseñanza es otra de las reformas cardinales que la revolución ha reclamado y que el gobierno provisional se ha apresurado a satisfacer sin pérdida de tiempo. Los

41 Sobre el particular vid. SouTo PAZ, J. A., Comunidad política y libertad de creencias. Introducción a las libertades públicas en el Derecho Comparado, Madrid, 1999.

42 "Manifiesto...», cit., pág. 225. 
excesos cometidos en estos últimos años por la reacción desenfrenada y ciega, (...) ese estado de descomposición a que había llegado la instrucción pública en España, merced a planes monstruosos, impuestos, no por las necesidades de la ciencia, sino por las estrechas miras de partido y de secta; ese desconcierto, esa confusión, en fin, cuyas consecuencias hubieran sido funestísimas a no llegar tan oportunamente el remedio, han dado al Gobierno provisional la norma para resolver la cuestión de la enseñanza, de manera que la ilustración en vez de ser buscada vaya a buscar al pueblo, y no vuelva a verse el predominio absorbente de escuelas y sistemas más amigos del monopolio que de la controversia» ${ }^{43}$.

La unidad e interdependencia de las libertades públicas, que constituye hoy doctrina común y fundamental de Naciones Unidas en materia de derechos humanos, aparece enunciada de manera explícita en el Manifiesto del Gobierno Provisional, al reafirmar que: « como natural resultado de la libertad religiosa y de la libertad de imprenta, sin la cual aquellas conquistas no serian más que fórmulas ilusorias y vanas (..). Las libertades de reunión y de asociación pacíficas, perennes fuentes de actividad y progreso, que tanto han contribuido en el orden político y económico al engrandecimiento de otros pueblos. Han sido asimismo reconocidas como dogmas fundamentales por la revolución españolan ${ }^{44}$.

La enumeración de estas libertades especializadas concluye con una nueva referencia a la libertad como motor del nuevo régimen político: «Desde hoy el pueblo español es responsable porque es libre, y con su constancia, su energía y su trabajo, noble y ordenadamente dirigido, puede y debe recobrar el tiempo perdido en el ocio de su pasada servidumbre, ocupando en el consenso de las Naciones el puesto que le corresponde por sus tradiciones históricas y por los medios de acción que ha reconquistado" ${ }^{45}$.

\section{Las libertades públicas en el debate de las Cortes Constituyentes}

El Manifiesto del Gobierno provisional expresa el espíritu de la Revolución del 68, que encontrará su consagración definitiva en la Cons-

\footnotetext{
43 Ibidem.

44 lbidem.

45 lbidem.
} 
titución del $69 \mathrm{y}$, por tanto, en el reconocimiento más amplio y garantista de las libertades públicas. "Por primera vez - dirá Tomás y Valiente - en la historia de nuestro constitucionalismo, aparecen en el proceso constituyente de 1868-1869 expresiones como libertades públicas o derechos fundamentales. No es casual. No surgen en obras académicas, no se pronuncian en la cátedra, sino en la tribuna parlamentaria. Su sentido es, sin embargo, claro. Aluden a una realidad jurídica que no está a disposición del legislador, que pertenece a todo hombre, y que el constituyente más que definir debe simplemente garantizar» ${ }^{46}$.

En el debate parlamentario, Ríos Rosas pone especial énfasis en este hecho: "Es verdad, señores, que el germen de los derechos individuales, que algunos de los derechos individuales han aparecido con más o menos extensión en las constituciones precedentes; pero así como es verdad, es verdad también que en su extensión, en su compaginación, en su importancia, en su desarrollo, en su desenvolvimiento, no han aparecido en ninguna como en ésta» ${ }^{47}$. Ciertamente, ninguna Constitución precedente española, ha elaborado un catálogo tan amplio de derechos y libertades públicas como la Constitución de 1869. Pero, aun siendo este hecho relevante y de gran importancia, llama más la atención el empeño de los constituyentes en resaltar la preexistencia de estos derechos al propio texto constitucional, subrayando la naturaleza intrínseca humana e «ilegislable» de estos derechos, y los mecanismos garantistas que para su efectiva vigencia establece el propio texto constitucional ${ }^{48}$.

Aunque los dos grandes objetivos de la Revolución del 68 han sido la expulsión de la dinastía borbónica y la implantación de las libertades públicas y de los derechos "ilegislables" 49 , lo cierto es que para los constituyentes la cuestión de la forma de gobierno es secundaria al de las libertades públicas. "Yo lo que digo - afirmará el diputado

46 TOMAS Y VALIENTE, F., "Los derechos fundamentales en la historia del Constitucionalismo español», en Introducción a los Derechos Fundamentales, vol. I, Madrid, 1988, pág. 47.

47 "Discurso de 9 de abril", en Monarquía y democracia en las Cortes de 1869. Discursos parlamentarios. Selección de Textos y estudio preliminar de Antonio María Calero, Centro de Estudios Constitucionales, Madrid,1987, pág. 38.

48 Como comenta Tomás VILLARRoYA, "la Constitución regulaba con generosidad todos y cada uno de los derechos que reconocía; y si, en relación a alguno, consideraba fijar su extensión y límites, cuidaba de hacerlo por sí misma... De esta manera, la Constitución rehuía todo lo que pudiera suponer una traba inferior al ejercicio de los derechon (Breve Historia..., cit., pág. 87).

49 Tomás y VALIENTE, F., op. cit., pág. 44. 
Moret - es que los derechos individuales nacen del espíritu que domina en la Constitución, y que son independientes en su desarrollo de la forma de gobierno, la cual no es más que el manto con que se cubre la sociedad ${ }^{50}$.

La definición de la forma de gobierno es una opción de los constituyentes; el reconocimiento de los derechos y libertades públicas es una obligación que nace del carácter preexistente de estos derechos, tanto respecto a la Constitución como a la forma de gobierno. La referencia a estos derechos dará lugar a un debate singular en torno a su condición de derechos «ilegislables». De manera rotunda dirá Castelar que: "si a alguna cosa se puede llamar derechos divinos es a los derechos fundamentales ilegislables" ${ }^{51}$. No les resultó fácil a los diputados encontrar una terminología unívoca para referirse a estos derechos y libertades, necesitando recurrir a la metáfora, tanto para describirlos como para garantizar su eficacia. Con estas palabras pretende definirlos el ya citado Moret: "No se declaran los derechos, decía SS. $Y$ no se declaran, estamos perfectamente de acuerdo; no se declara que el hombre tiene corazón y cabeza...; lo que se define por la Constítución es la manera de ejercitar el derecho en cuanto toca, en cuanto se relaciona con los demás. Esto es lo que se ha hecho; y para no caer en ese error, no hemos legislado, como los americanos, que únicamente entienden que se debe legislar diciendo: se prohíbe esto, no se tolerará, ya se permitirá aquello, etc. Aquí el derecho va implícito, y lo que se trata es de garantizar su ejercicio, que en él no ocurran dificultades» ${ }^{52}$.

Ciertamente, pareció existir una cierta confusión en los debates parlamentarios entre el origen de los derechos y su ejercicio. El origen de los derechos y de las libertades fundamentales trae su causa de la dignidad humana y ello se ha expresado de muy distintas maneras: derechos naturales, derechos humanos, derechos inalienables,

50 "Discurso de 8 de abril", en Monarquía y Democracia en las Cortes de 1869, Discursos parlamentarios, op. cit., pág. 59.

51 "Discurso de 12 de abril", en Diario de Sesiones, n. ${ }^{\circ} 47$, pág. 990.

52 En Monarquía y democracia..., op. cit., pág. 17, TORRES DEL MORAL califica esta opción del constituyente como la profesión de «acusado iusnaturalismo racionalista, conforme al cual los derechos individuales son naturales, como lo son la respiración y la circulación de la sangre; son inalienables y anteriores a toda legislación; son ilegislables... llegislable venía a decir no susceptible de restricciones por la ley ni de medidas preventivas que dificultaran su ejercicio; los abusos a que pudieran dar lugar sólo deberían sancionarse a posteriori por los tribunales" (Constitucionalismo histórico..., cit., pág. 103). 
derechos fundamentales, etc. Cualquiera de estas denominaciones pretende expresar que los "derechos del hombre» - utilizando la terminología de Thomas Paine - son preexistentes a cualquier norma jurídica, incluida la Constitución, que, en todo caso, se limita a reconocer su existencia y a garantizar su ejercicio. Esta concepción explica que la Constitución incluya una cláusula de numerus apertus de derechos y libertades fundamentales, al decir, en su artículo 29 que: «la enumeración de los derechos consignados en este título no implica la prohibición de cualquier otro no consignado expresamente".

La naturaleza de estos derechos, estrechamente vinculados a la dignidad humana, no admite un elenco taxativo y exclusivo de derechos, pues, cualquier nueva situación producida por las innovaciones sociales o tecnológicas -datos informáticos, transplantes de órganos o el genoma humano, etc.-, da lugar a que se "descubran» nuevos derechos humanos, al entrar en juego la dignidad y libertad de la persona ante una nueva realidad social, que exige el amparo y la protección de la persona humana.

Los constituyentes del 69 mostraron su preocupación por garantizar estos derechos preexistentes a la propia Constitución, reconocerlos expresamente y dejar abierta la puerta para el reconocimiento de otros, en vía normativa o judicial, y, sobre todo, la necesidad de garantizar que estos derechos son inalienables y no pueden ser revocados, suprimidos o vaciados de contenido por el poder legislativo $y$, mucho menos, por el poder ejecutivo. En este contexto surge el debate y la singular terminología de los derechos «ilegislables».

El debate sobre el carácter ilegislable de estos derechos prueba la presencia y, probablemente, la influencia de la revolución americana y de sus textos fundamentales en la elaboración de la Constitución del 6953. Entre otros diputados, destaca, en este sentido, la expresiva referencia a la Constitución norteamericana del diputado Orense para explicar la «ilegislabilidad" de estos derechos. En respuesta al diputado Álvarez, Orense afirma lo siguiente: "...le diré lo que sucede en Estados Unidos. Si allí el Congreso da una ley que ataca estos derechos, ésta se tiene por no dada, y al ciudadano a quien se forma, por ejemplo, una causa de imprenta, en vez de atacar al Congreso, se ríe, acude ante lo que nosotros Ilamamos Tribunal Supremo de Justicia, y allí se llama Corte de Casación Federal, la cual declara que esa ley no

53 Sobre el particular, v. OLtRA, J., La influencia norteamericana en la Constitución Española de 1869, Madrid, 1972. 
puede aplicarse a aquel ciudadano y virtualmente la decisión de la Cámara produce el mismo efecto que si no se hubiera dado. En este sentido se llaman "ilegislables" estos derechos..." ${ }^{54}$.

La interpretación de los constituyentes, atribuyendo a estos derechos el carácter de ilegislables, parece errónea, pues una cosa es que la ley no pueda suprimir estos derechos y otra distinta es que la ley no pueda regular su ejercicio. Así, en la Carta de Privilegios de Pennsylvania (1701), se dice que: " ningún acto, ley y ordenanza podrá, en adelante, alterar, modificar, o disminuir la forma o los efectos de esta Carta, o cualquiera de sus partes o cláusulas, contraviniendo su espíritu o su significado.... ${ }^{55}$. Y, en la Declaración de Derechos y Normas Fundamentales de Delaware (1776), se dice expresamente: "Que las personas responsables del poder ejecutivo y del poder legislativo son los depositarios y administradores del Gobierno y, como tales, responsables de su marcha; si los fines del gobierno llegaran a pervertirse y la libertad pública peligrara de forma manifiesta a causa del poder legislativo o de un pacto fraudulento de ambos poderes, el pueblo debe establecer, de acuerdo con el Derecho, un nuevo Gobierno, o remodelar el antiguo» 56 .

Esta cláusula está directamente relacionada con la Declaración de Independencia de los Estados Unidos de América (1776), en la que se dice: "Sostenemos por evidentes, por sí mismas, estas verdades: que todos los hombres son creados iguales; que son dotados por su creador de ciertos derechos inalienables; entre los cuales están la vida, la libertad y la búsqueda de la felicidad; que para garantizar estos derechos se instituyen entre los hombres, los gobiernos, que derivan sus poderes legítimos del consentimiento de los gobernados; que siempre que una forma de gobierno se haga destructora de estos principios, el pueblo tiene el derecho a reformarla o a abolirla e instituir un nuevo gobierno...".

En la ecuación derechos y libertades fundamentales e institución del gobierno parece que se encuentra la correcta interpretación de la Ilamada ilegislabilidad de estos derechos. Significa que ni el legislativo ni el ejecutivo pueden suprimir o dejar sin contenido esos derechos, pues la finalidad del gobierno es, precisamente, garantizar su vigencia y ejercicio. La legislación que desarrolle el ejercicio de estos dere-

DS, 56, 1291.

"Carta de Privilegios de Pennsylvania", VIII.

Art. 5. 
chos, si no los suprime o vacía de contenido, es perfectamente compatible con la naturaleza de los derechos y la función del poder legislativo ${ }^{57}$.

Tampoco parece acertada la distinción entre «derechos de tal modo inalienables que el Estado no puede ni siquiera regular su ejercicio, y aquellos otros que, aun permaneciendo como naturales son - por las necesidades sociales - regulados no en su origen, sino en su ejercicio. Los primeros son derechos sobre los que el gobierno no tiene la facultad de legislar ni indirectamente, y que podríamos llamar ilegislables, aunque la denominación no sea corriente entre los teóricos americanos. Estos derechos son los cuatro enumerados en la enmienda l, después de la declaración absoluta de que "el Congreso no legislará sobre.... ${ }^{58}$.

Esta afirmación no deja de ser sorprendente, por cuanto la Primera Enmienda dice, ciertamente, que el Congreso no dictará leyes sobre las siguientes cuestiones:

1) estableciendo una religión;

2) prohibiendo el uso de la misma;

3) limitando la libertad de prensa o palabra;

4) limitando el derecho del pueblo a reunirse;

5) limitando el derecho de petición al gobierno para la reparación de sus agravios.

No se trata de una prohibición absoluta de legislar sobre estas materias, sino de legislar vulnerando las especificaciones expresamente contenidas en la Primera Enmienda 59 , es decir, prohibiendo o

57 Esta controversia hoy está plenamente superada, al reconocer la competencia del poder legislativo para regular el ejercicio de estos derechos y libertades (reserva de ley), prohibiendo al Ejecutivo esta función. En todo caso, la ley deberá respetar el contenido esencial de ese derecho y ser aprobada por una mayoriá cualificada, recibiendo en nuestro derecho vigente la calificación de ley orgánica.

58 OLTRA, op. cit., pág. 110.

59 Como explicó el Presidente de la Corte Suprema Burger: «En esta área incluso el análisis debe comenzar con la consideración de los criterios acumulativos elaborados por la Corte a lo largo de muchos años. De nuestros casos podemos extraer tres de dichas piedras de toque. Primero, la ley ha de perseguir un propósito legislativo secular; segundo, su efecto principal o primario ha de ser tal que no promueva ni inhiba la religión; finalmente, la ley no debe promover un excesivo compromiso oficial con la religión...) (CORWIN, E. S., La Constitución de los Estados Unidos y su significado actual, trad. esp. Buenos Aires, 1987, pág. 377). 
limitando el ejercicio de esos derechos. La prohibición al Congreso de legislar, en ese sentido, ha sido extendida a los demás Estados a través de la Decimocuarta Enmienda que, en todo caso, prohíbe cualquier legislación que límite los derechos o las inmunidades de los ciudadanos de los Estados Unidos. De igual manera, se prohíbe que cualquier Estado pueda privar a una persona de la vida, de la libertad o de la propiedad sin el debido proceso legal (Due Process clause)60.

La preocupación de los constituyentes, en relación con el pleno reconocimiento y vigencia efectiva de las libertades públicas, que provocó el debate sobre los derechos ilegislables, se resolvió, en nuestra opinión, acertadamente con la prohibición establecida en el artículo 22, según el cual: «No se establecerá ni por las leyes ni por las Autoridades disposición alguna preventiva que se refiera al ejercicio de los derechos definidos en este título. Tampoco podrán establecerse la censura, el depósito ni el editor responsable para los periódicos".

Entre las garantías jurídicas establecidas por la Constitución del 69, destaca ciertamente la opción por el sistema represivo y la prohibición del sistema preventivo. Con ello, la Constitución se adelantó en muchos años a la implantación de este sistema en los regímenes constitucionales contemporáneos. La garantía de estos derechos tiene una explicación plausible en los diputados constituyentes: "La razón de esta preocupación - nos dirá Oltra - por los derechos individuales es bien clara: la experiencia de los diputados del 69 en un pasado nada lejano - menos de medio año- pesaban fuertemente en su ánimo; todos o casi todos, habían sufrido una forma $u$ otra de persecución por parte del o de los gobiernos desaparecidos y como natural reacción psicológica les interesa asegurarse de que el hecho no vuelva a ocurrir. Su preocupación fundamental es, pues, no el restablecer un gobierno estable, sino todo lo contrario: el establecer un gobierno, de la forma que sea, en el que se respeten las libertades individuales» ${ }^{61}$.

60 «Para los fines actuales podemos suponer $y$ en efecto suponemos que la libertad de palabra y de prensa - protegidas por la primera Enmienda de los recortes que pueda imponerle el Congreso - se encuentran entre los derechos personales fundamentales y las libertades protegidas por la Cláusula del Debido Proceso de la Décimo Cuarta Enmienda del menoscabo que puedan infligirle los Estados» (Corwin, E. S., op. cit., pág. 609).

61 lbidem. En un sentido semejante se manifiesta Merino Merchán, J. F., al decir: "El verdadero significado de considerar ilegis/ables a los derechos reconocidos en el texto constitucional, estaba en adoptar una medida general de prevención contra las limitaciones que pudieran interponerse por la Autoridad para su libre ejercicio: Pesaba la memoria reciente del pasado isabelino, en que el libre 


\section{EL CATÁLOGO DE LIBERTADES EN LA CONSTITUCIÓN DE 1869}

\section{Una declaración sin precedentes en el constitucionalismo español}

La Constitución de 1869 se inicia con una declaración de derechos, siguiendo el modelo de las Constituciones contemporáneas que integran una parte dogmática y otra orgánica. Desde un punto de vista iuscomparatista, guarda gran semejanza con la Constitución belga de 1831 y con la francesa de 1848, si bien la Constitución española establece una serie de garantías jurídicas que no se encuentran en ninguna de esas Constituciones.

En cuanto al derecho constitucional español, la Constitución de 1869 es profundamente innovadora en el reconocimiento de libertades públicas y garantías jurídicas. Carecen de antecedentes: el sufragio universal, la inviolabilidad de la correspondencia, el habeas corpus, la exigencia de intervención judicial para la expropiación de bienes, la libertad de expresión, reunión, asociación y petición colectiva; la libertad de cultos, la libertad de enseñanza; la libertad de ejercicio profesional y de empresa para españoles y extranjeros; la libertad de establecimiento de extranjeros en territorio español; la libertad de circulación y residencia, incluso en el extranjero; la libertad de acceso a la función pública. Resulta novedoso, también, como advertimos anteriormente, el carácter abierto de este catálogo de derechos, frente al habitual numerus clausus, la prohibición de suspensión de algún derecho con carácter preventivo y las garantías jurisdiccionales previstas para el ejercicio efectivo de estos derechos.

La sistemática seguida por los constituyentes obedece a la distinción de los derechos y libertades de la persona en su dimensión física y en su dimensión espiritual, a los que cabe añadir los derechos específicos como ciudadano (libertades políticas) y como homo faber (libertades socioeconómicas), si bien, muchos de ellos, se incluyen hoy entre los derechos y libertades civiles ${ }^{62}$ : libertad profesional, de empresa y de acceso a la función pública y derecho de sufragio.

ejercicio de los derechos estaba sujeto a fuertes restricciones políticas por Decretos de Autoridad" (Regímenes históricos españoles, Madrid, 1995, pág. 121).

62 La Constitución española vigente incluye entre los derechos civiles: el derecho a la propiedad (art. 33); la libertad de trabajo y profesión (art. 35) y la libertad de empresa (art. 38). El derecho de acceso a la función pública y el derecho al voto se encuentran regulados entre los derechos y libertades fundamentales (art. 23). 


\section{Libertades de la persona física. Libertad y seguridad}

\subsection{Inviolabilidad personal}

La Constitución dedica su artículo 2. a la libertad personal, prescribiendo que: «ningún español ni extranjero podrá ser detenido ni preso sino por causa de delito». La detención gubernativa no podrá durar más de 24 de horas, pues "todo detenido será puesto en libertad o entregado a la Autoridad Judicial dentro de las 24 horas siguientes al acto de la detención" (art. 3). La detención judicial sólo podrá durar 72 horas, por lo que, o se deja sin efecto o se eleva a prisión, mediante mandamiento judicial, dando audiencia al reo, que será ratificado o repuesto en el plazo de 72 horas siguientes al acto de la prisión (art. 4).

La libertad personal se configura, así, como un derecho subjetivo, evitando las detenciones gubernamentales ilegales sin limitación de tiempo. Por otra parte, la detención será, en cualquier caso, ilegal si no es por causa de delito, por lo que sería ilegal cualquier detención con fines distintos de la inquisición del delito. Las garantías jurídicas establecidas por la Constitución de 1869 significan un avance considerable en relación con las Constituciones precedentes y, en especial, por excluir que pudieran ser desvirtuadas por su remisión a la ley.

Desde la perspectiva actual y considerada la libertad personal como una dimensión física de la persōna, llama la atención el contraste entre una protección jurisdiccional tan precisa respecto a la libertad personal y la ausencia total, incluso de su mención, de otros aspectos fundamentales de la persona física. Así, aunque la versión positiva de algunos derechos, como el derecho a la vida o a la integridad física, todavía no habían sido formulados en el derecho comparado, sorprende la negativa de los constituyentes a la abolición de la pena de muerte, propuesta insistentemente por los diputados republicanos 63 , y de la cual ya existían antecedentes en la Constitución francesa de 1848 (art. 5), al menos en relación con el ámbito político, y la Constîtución argentina de 1853 (art. 18). Otro tanto ocurre con la abolición de la esclavitud y de la tortura de la que, también, existen precedentes en las Constituciones citadas (art. 6 y arts. 154,18$)^{64}$.

63 El diputado Sánchez Yago y otros diputados republicanos firmaron una enmienda que decía así: "A ningún español podrá imponerse la pena de muerte ni de argolla" (Diario de Sesiones, $n .^{\circ} 50$, pág. 1082).

64 Ambas cuestiones fueron reguladas con desigual fortuna a lo largo del siglo $\mathrm{XIX}$ por normas de rango inferior, pero, en ningún caso, llegaron a abolirse (Romero Moreno, J. M., op. cit., págs. 127 y ss.). 


\subsection{Inviolabilidad del domicilio}

La Constitución de 1869 reconoce la inviolabilidad del domicilio (art. 5). Considerado el santuario de la privacidad personal y familiar, la inviolabilidad del domicilio constituye uno de los derechos más antiguos reconocidos en las Declaraciones históricas de derechos. La Cuarta Enmienda de la Constitución de los Estados Unidos reconoce este derecho ${ }^{65}$ y lo mismo hace, en nuestro derecho histórico, la Constitución de 1812: "No podrá ser allanada la casa de ningún español, sino en los casos que determine la ley para el buen orden y seguridad del Estado " ${ }^{66}$. Este derecho se reitera en las Constituciones de $1837^{67}$ y $1845^{68}$.

Las diferencias fundamentales entre estos preceptos constitucionales y la regulación del 69 van a residir nuevamente en las garantías jurídicas establecidas, que refuerzan la efectividad del derecho reconocido. Frente a las remisiones a las leyes para la regulación de este derecho, que realizan las Constituciones precedentes, la Constitución de 1869 establece directamente la regulación del derecho constitucionalizado, impidiendo que pueda vaciarse de contenido por el procedimiento habitual de su remisión a la legislación ordinaria.

Los constituyentes precisan que «nadie podrá entrar en el domicilio de un español o extranjero residente en España sin su consentimiento" "69. Reafirmada la inviolabilidad del domicilio y la necesidad del consentimiento de su titular para acceder a la misma, establece las siguientes excepciones:

1) Casos de urgencia o necesidad: se incluyen aquí los supuestos de incendio, inundación u otro peligro análogo, la agresión ilegítima procedente de adentro (desde el interior del domicilio) o la necesidad de prestar auxilio a persona que desde allí pida socorro.

65 «El derecho de los ciudadanos a la seguridad de las personas, domicilio, papeles y efectos contra pesquisas y embargos arbitrarios es inviolable; no se decretará entrada y registro alguno sin motivo fundado y corroborado por palabras de honor o juramentos o sin que se determine el lugar que debe de ser objeto de reconocimiento y las personas o cosas de las que haya que apoderarse".

66 Art. 306.

67 «No puede ser detenido, ni preso, ni separado de su domicilio ningún español, ni allanada su casa sino en los casos y en la forma que las leyes prescriban» (art. $\left.7 .{ }^{\circ}\right)$.

68 "No puede ser detenido, ni preso, ni separado de su domicilio ningún español, ni allanado su casa sino en los casos $y$ en la forma que las leyes prescriban". (art. $\left.7 .{ }^{\circ}\right)$.

69 Art. 5. 
2) Con mandamiento judicial: La entrada en el domicilio de un español o extranjero residente en España y el registro de sus papeles o efectos, sólo podrá decretarse por Juez competente y ejecutarse de día, en presencia del interesado o de un individuo de su familia y, en su defecto, de dos testigos vecinos del mismo pueblo.

3) Persecución de un delincuente in fraganti: Cuando un delincuente hallado in fraganti y perseguido por la autoridad o sus agentes se refugiare en su domicilio, podrán éstos penetrar en el domicilio sólo a los efectos de la aprehensión. Sin embargo, si se refugiare en domicilio ajeno, se requerirá la autorización del dueño.

La inviolabilidad del domicilio, configurada en la Constitución del 69 , como un derecho subjetivo directamente ejercitable ante las autoridades judiciales en caso de violación, forma parte del derecho a la privacidad individual y familiar y constituye el ámbito de libertad más amplio y pleno de la persona humana. Esa esfera de libertad incluye, lógicamente, la libertad de elección de domicilio, por lo que la Constitución dispone que: «ningún español podrá ser compelido a mudar de domicilio o de residencia sino en virtud de sentencia ejecutiva" 70 . Nuevamente se observa el reforzamiento de las garantías jurídicas que afectan a estos derechos; la Constitución garantiza la libertad de domicilio y residencia hasta el extremo de que no se podrá prohibir, limitar o suspender este derecho, salvo mediante procedimiento judicial, que termine con sentencia ejecutoria y que comporte la condena a mudar de domicilio o de residencia.

Completa este derecho a la elección de domicilio y residencia, la prohibición establecida en el artículo 26, según el cual: " a ningún español que esté en el pleno goce de sus derechos civiles podrá impedirsele salir libremente del territorio, ni trasladar su residencia y haberes a país extranjero, salvas las obligaciones de contribuir al servicio militar o al mantenimiento de las cargas públicas». El precepto constitucional reconoce, así, por primera vez el derecho de libertad de circulación, extendiéndolo más allá del territorio nacional y vinculándolo a la libre elección de residencia y de domicilio en el extranjero. No deja de ser curioso que se reconozca expresamente el derecho de circulación más allá de las fronteras españolas, sin hacer mención expresa de la libertad de circulación dentro del territorio 
nacional ${ }^{71}$. En el debate parlamentario se presentó una enmienda para que se suprimiese la carta de vecindad que se exigía para poder viajar. Se consideró por la Comisión que no era necesario aceptar dicha enmienda, dado que la supresión de la necesidad de ese documento para circular estaba implícita en el contenido del precepto constitucional72.

\subsection{Inviolabilidad de la correspondencia}

Se trata de un derecho de libertad, que hoy podríamos definir como clásico, si bien, en nuestro derecho, su reconocimiento por la Constitución de 1869 carecía de precedentes constitucionales. Está reconocido, sin embargo, en la Constitución belga de $1831^{73}$. El artículo 7 de la Constitución de 1869 reconoce de manera explícita el derecho a la libertad y privacidad de la correspondencia, prohibiendo su violación por parte de las autoridades: «En ningún caso podrá detenerse ni abrirse por la Autoridad gubernativa la correspondencia confiada al correo, ni tampoco detenerse la telegráfica». El ejercicio de este derecho sólo podrá quedar suspendido por decisión judicial: "Pero en virtud de auto de Juez competente podrá detenerse una y otra correspondencia, y también abrirse en presencia del procesado la que se le dirija por el correo».

\subsection{Garantías jurisdiccionales comunes}

Los derechos constitucionales que afectan a la libertad y segu: ridad personal, además de las garantías jurídicas de naturaleza sustantiva establecidas en los artículos anteriores, son agrupados en la Constitución a los efectos de establecer unas garantías jurisdiccionales comunes, que se pueden sintetizar en los siguientes aspectos:

71 GonzÁlez-TreviJAno, P. J., advierte que, aun cuando este derecho se reconoce constitucionalmente por primera vez en la Constitución de 1869 , sin embargo, con anterioridad se encontraba comprendido dentro del ámbito de la libertad personal (Libertades de circulación, residencia, entrada y salida de España, Madrid, 1991, pág. 63).

72 Carro Martínez, A., La Constitución de 1869, cit., págs. 239-240.

73 Art. 22: «El secreto de la correspondencia es inviolable. A ley determinará quiénes son los agentes responsables de la violación del secreto de la correspondencia entregada la correo". 
a) Motivación de las resoluciones judiciales

Se establece con carácter general que todo auto de prisión, de registro de morada o de detención de la correspondencia escrita o telegráfica será motivado ${ }^{74}$. La ausencia de motivación o la insuficiencia de los motivos alegados, probados judicialmente, darán lugar a indemnización propercionada al daño causado por parte del Juez y en beneficio de la persona lesionada en su derecho. Incurrirán en responsabilidad, igualmente, los agentes de la Autoridad que reciban en prisión a cualquier persona sin mandamiento judicial o la retengan, sin que dicho auto haya sido ratificado dentro del término legal. En ambos supuestos los agentes estarán obligados a indemnizar a las personas afectadas en la cuantía que establezca el juez.

b) Tipificación de los delitos de detención arbitraria y allanamiento de morada

Los jueces y agentes de la autoridad, que vulneren los requisitos constitucionales establecidos para proceder a la detención de una persona o para acceder a un domicilio, incurrirán en una actuación delictiva, tipificadas, en cada caso, como delito de detención arbitraria y de allanamiento de morada ${ }^{75}$. La condena a los autores de los citados delitos, que puedan derivarse del correspondiente proceso judicial, no les eximirá del abono de la indemnización que proceda a las víctimas de sus actuaciones ilegales.

En el mismo supuesto incurrirán tanto el agente de la autoridad que incumpla el plazo previsto para la entrega de un detenido a la autoridad judicial como ésta última cuando no la elevare a prisión, dentro del plazo previsto constitucionalmente. En ambos casos, los autores deberán indemnizar a los detenidos.

\section{c) Competencia del juez natural}

El conocimiento judicial de los supuestos contemplados en los apartados precedentes corresponderá a los jueces predeterminados

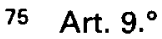


legalmente. Así, «ningún español podrá ser procesado ni sentenciado sino por el Juez o Tribunal a quien, en virtud de las leyes anteriores al delito, competa el conocimiento y la forma que éstas prescriban. No podrán crearse Tribunales extraordinarios ni comisiones especiales para conocer de ningún delito" ${ }^{76}$.

\section{d) Procedimiento de habeas corpus}

Además de las responsabilidades derivadas de las actuaciones arbitrarias o delictivas, en que puedan incurrir las autoridades judiciales, gubernativas o sus agentes, en los supuestos antes descritos, procede que: "Toda persona detenida o presa sin las formalidades legales o fuera de los casos previstos en la Constitución, será puesta en libertad a petición suya o de cualquier español. La ley determinará la forma de proceder sumariamente en este caso, así como las multas personales y pecuniarias en que haya de incurrir el que ordenare, ejecutare o hiciere ejecutar la detención o prisión legal»’77.

\section{Libertades del espíritu 78}

\subsection{El mundo de las ideas y creencias: interpretación jurídica}

El hombre como ser racional dispone de una capacidad potencial para elaborar su propia concepción de la vida o cosmovisión, fruto de una argumentación racional o de una adhesión fideística. Las creencias religiosas o ideológicas constituyen la "tierra firme", en expresión orteguiana ${ }^{79}$, que permite al hombre desenvolverse en la esfera personal o social, de acuerdo con unos parámetros que asegu-

76 Art. 11.

77 Art. 62.

78 Utilizamos la terminología acuñada por la doctrina francesa, en contraposición con la libertad física, a que nos referimos anteriormente, y que se trata de la libertad de cada individuo de adoptar, en cualquier ámbito que se trate, la actitud intelectual de su elección, ya se trate de una actitud interior, de un pensamiento intimo o de una toma de posición pública. "En somme, liberté pour chaque homme de penser et de dire ce qu'il croit vrai. C'est un aspect essentiel de la liberté de l'esprit" (RoBeRT, J., Droits de I'homme et libertés fondamentales, $6 .^{\circ}$ de., págs. 528 y ss.).

79 Ortega y Gasset, Ideas y creencias, 8. a edición, Madrid, 1976, pág. 35. 
ran un comportamiento coherente con las propias convicciones personales.

Más allá del mundo de las convicciones íntimas y fundamentales de cada ser humano, su capacidad reflexiva le permite formular juicios u opiniones sobre las más diversas cuestiones que acontecen en su vida personal o en su entorno. El mundo de las ideas y creencias comporta una dimensión específica del ser humano, que denota su singularidad entre los seres vivos y sirve de fundamento a su condición de persona y a la dignidad que le es inherente.

¿Es libre el hombre de conformar su propio mundo de ideas y creencias? He aquí una cuestión clave que, durante un largo período de la vida de la humanidad, ha tenido una respuesta negativa. El mundo de las creencias, limitadas tradicionalmente a las creencias religiosas, ha estado condicionado por su vinculación a una determinada comunidad social o política. Las creencias son comunitarias, pertenecen a la comunidad, como resultado del legado de los antepasados, por lo que el individuo carece de libertad para elegir sus creencias, puesto que las creencias comunitarias constituyen un deber ciudadano, cuya violación se configura como un delito muy grave, que puede comportar la pena capital ${ }^{80}$. La historia revela, al mismo tiempo, que la inflexibilidad en el campo de las creencias se ha compaginado con una cierta libertad fáctica en el ámbito de las ideas. Esta "libertad fáctica", no obstante, se ha visto amenazada por dos vías distintas que, en ocasiones, han confluido hasta el punto de identificarse.

El primer flanco abierto a la libertad de ideas proviene de la dimensión cultural y civilizadora de las creencias religiosas, que no se han limitado a describir un futuro transcendente, sino que, en nombre de los dioses y a través de sus representantes oficiales, han impuesto comportamientos individuales y sociales que han podido colisionar con las «ideas" personales, en las que lógicamente la libertad individual se desvanecía en aras de la supremacía de la voluntad de los dioses o de las tradiciones comunitarias.

Un segundo flanco se advierte en la posible y probable confrontación entre las decisiones del poder político y la libertad de ideas. Al no estar configurada esta última como un derecho subjetivo, con las

80 Souto Paz, J. A., La Comunidad política y la libertad de creencias..., op. cit., págs. 11 y ss. 
consiguientes garantías jurídicas, el individuo se ha encontrado siempre en una situación de manifiesta inferioridad frente al poder político, por lo que la represión de las ideas y de las críticas al poder político han sido una constante a lo largo de la historia. Con frecuencia, y para asegurar la auctoritas del poder político, se ha producido una «divinización" o "sacralización» del titular del poder ${ }^{81}$, produciéndose, asi, una confluencia manifiesta entre el mundo de las creencias religiosas y el mundo de las decisiones políticas, ante las cuales la libertad de ideas del individuo quedaba absolutamente inerme.

Las consideraciones precedentes parecen oportunas para la comprensión de las libertades del espiritu, garantizadas en la Constitución de 1869. Su artículo 17 dispone que ningún español podrá ser privado:

a) Del derecho de emitir libremente sus ideas y opiniones, ya de palabra, ya por escrito, valiéndose de la imprenta o de otro procedimiento semejante.

b) Del derecho de reunirse pacificamente.

c) Del derecho de asociarse para todos los fines de la vida humana que no sean contrarios a la moral pública.

d) Del derecho de dirigir peticiones individual o colectivamente a las Cortes, al Rey y a las Autoridades.

La Constitución progresista reconoce, así, como libertades estrechamente relacionadas y vinculadas entre sí, la libertad de expresión, la libertad de reunión, la libertad de asociación y la libertad de petición individual y colectiva. ¿Estas libertades se refieren al mundo de las ideas o comprenden también el mundo de las creencias? ¿Se circunscribe a la libertad de pensamiento o incluye, también, la libertad religiosa?

No cabe la menor duda que los constituyentes han operado con el esquema europeo de diferenciar libertad de pensamiento y libertad religiosa, que tiene su origen en el proceso revolucionario fran-

81 Como ejemplo manifiesto de este proceso se puede observar la progresiva sacralización y divinización de los emperadores romanos, a partir de Augusto, que se apropian de la magistratura de pontifex maximus, anteriormente electiva, para acabar convirtiéndose en dioses. Una proyección semejante se encontrará, más tarde, reflejada en el derecho divino de los reyes (NEVILLE FIGGIS, J., El derecho divino de los reyes, 1896. Edición del Fondo de Cultura Económica, México, 1942). 
cés $^{82}$, frente a la fórmula norteamericana que no distingue entre ambas, al incluir, en la Primera Enmienda, la libertad de religión, de palabra y prensa y las de reunión y petición.

El texto español parece inspirarse en la Constitución francesa de 1848 que, en su artículo 8, dice: "Los ciudadanos tienen el derecho de asociarse, de reunirse pacíficamente, de manifestar sus pensamientos por vía de la prensa o de otra forma. El ejercicio de estos derechos no tiene más límites que los derechos o la libertad de otros y la seguridad pública. La prensa no puede, en ningún caso, ser sometida a la censura».

En cambio, en el artículo precedente (art. 7), se reconoce que: "Cada uno puede profesar libremente su religión, y recibe del Estado, para el ejercicio de su culto, una igual protección. Los ministros, bien de cultos reconocidos actualmente por la ley, bien de aquéllos que sean reconocidos en el futuro, tienen derecho a recibir una remuneración por parte del Estado».

La regulación del derecho de libertad de pensamiento y de libertad religiosa en dos preceptos distintos es seguida por el constituyente español que, si bien regula la libertad de pensamiento en el artículo 17, como hemos visto, se refiere a la libertad religiosa en el artículo 21, en los siguientes términos: "La Nación se obliga a mantener el culto y los ministros de la religión católica. El ejercicio público o privado de cualquier otro culto queda garantizado a todos los extranjeros residentes en España, sin más limitaciones que las reglas universales de la moral y del derecho. Si algunos españoles profesaren otra religión que la católica, es aplicable a los mismos todo lo dispuesto en el apartado anterior".

El paralelismo entre el texto francés y el español no quiere decir identificación plena, pues, en el texto español, se aprecian todas las características de un precepto que ha requerido la cuarta parte del tiempo de debate dedicado a toda la Constitución. En el debate estuvieron presentes dos cuestiones: a) la confesionalidad vs. aconfesionalidad del Estado y la consiguiente separación Iglesia y Estado; b) el reconocimiento del derecho de libertad religiosa por primera vez en la historia del constitucionalismo español. Esta cuestión, sin embargo, merece un estudio aparte, por lo que vamos a concluir el análisis

82 Souto Galván, E., La libertad de opinión y libertad religiosa (Estudio histórico jurídico del artículo 10 de la Declaración francesa de los Derechos del Hombre y del Ciudadano), Madrid, 2001. 
del artículo 17 y las garantías jurídicas reconocidas constitucionalmente.

\subsection{La libertad de pensamiento y su proyección a través de otras libertades instrumentales}

La libertad de pensamiento pertenece al ámbito de las acciones interiores del hombre que el derecho no puede autorizar ni reprimir ${ }^{83}$. La exteriorización del pensamiento es lo que es susceptible de ser regulado por el derecho y sobre el que ha actuado vigorosamente el poder, generalmente, para reprimirlo. Como advierte Fichte: "La cuestión que queremos investigar aquí de si el príncipe tiene el derecho a restringir nuestra libertad de pensamiento se reduce a saber si el Estado puede tener tal derecho", pero, en realidad, aclara que: "Nos permitís pensar porque no podéis impedirlo, pero nos prohibís comunicar nuestros pensamientos; no ponéis en cuestión nuestro derecho inalienable a pensar libremente, sino sólo a comunicar lo pensado libremente 84 .

La libertad de pensamiento es, así, el origen de otras libertades como la libertad de expresión, libertad de educación, de asociación, de reunión, etc., que constituyen los cauces o instrumentos imprescindibles para comunicar los propios pensamientos. De ahí, que, si bien la libertad de pensamiento, en su dimensión más radical, no puede ser regulada jurídicamente, sin embargo, su reconocimiento implica que se garantiza el derecho a comunicar los propios pensamientos a través de las libertades antes expuestas.

A este respecto, se ha precisado que la libertad de tener pensamientos, creencias, etc., es un derecho absoluto e incoercible, es decir, que no se puede impedir o coartar; mientras que el derecho a manifestar los pensamientos, las creencias, etc., es un derecho limitado por los derechos y libertades de los demás y por el orden público protegido por la ley85.

83 "Las convicciones interiores, la veracidad, el respeto, el reconocimiento, el amor, se dan libremente y no se adquieren como derechos" (FICHTE, J. G., Reivindicación de la libertad de pensamiento a los Príncipes de Europa que hasta ahora la oprimieron. Discurso. 1793, Ed. Tecnos, Madrid, 1986).

84 Ibidem, págs. 17 y 19.

85 Declaración Universal de Derechos Humanos, n. 29. Se trata de una cláusula general que figura en todos los textos internacionales, entre otros, el Pacto 
Desde esta perspectiva, el artículo 17 de la Constitución de 1869 es un claro ejemplo del derecho de libertad de pensamiento, pues, aun sin referirse expresamente al mismo, enumera sus distintas manifestaciones, comenzando por la libertad de expresión. La Constitución española sigue el modelo francés que, después de reconocer que "nadie debe ser inquietado por sus opiniones, incluso religiosas, en tanto que su manifestación no altere el orden público establecido por la ley" ${ }^{86}$, añade que: "La libre comunicación de los pensamientos y de las opiniones es uno de los derechos más preciados del hombre; todo ciudadano puede, por tanto, hablar, escribir e imprimir libremente, salvo la responsabilidad que el abuso de esta libertad produzca en los casos determinados por la ley" 87 .

El artículo 17 de la Constitución de 1869 dice que: "Tampoco podrá ser privado ningún español: del derecho de emitir libremente sus ideas y opiniones, ya de palabra, ya por escrito, valiéndose de la imprenta o de otro procedimiento semejanten. La redacción es inédita en el derecho español, aunque guarda una estrecha relación con el derecho de libertad de imprenta 88 , reconocido en la Constitución de 1812, reproducido en la de 1837 (art. 2) y en la de 1845 (art. 2). En todos estos preceptos se garantiza la "libertad de escribir, imprimir y publicar sus ideas" (solamente las políticas en la Constitución del 12), sin necesidad de licencia o aprobación previa, bajo las restricciones y responsabilidades que establezcan las leyes.

El reconocimiento constitucional precedente a 1869 garantizaba la libertad de imprenta, suprimiendo la censura previa, y remitiendo su ejercicio a lo dispuesto en las leyes. Esta remisión ha sido, precisamente, el punto débil del reconocimiento constitucional, porque los Gobiernos utilizaron el Parlamento y la técnica legislativa para vaciar de contenido la libertad de imprenta, convirtiéndolo, en muchas ocasiones, en algo ilusorio.

Precisamente, los acontecimientos que precedieron a la Revolución del 68 pusieron en evidencia la ausencia de garantias jurídicas de la libertad de expresión frente a los abusos del poder. En 1864, el

Internacional de Derechos Civiles y Políticos (arts. 18.3; 19.3; $11 ; 22.2$; etc.), y el Convenio Europeo para la protección de los derechos humanos y las libertades públicas (1950), arts. 8.2, 9.2, 10.2, 11.2, etc.

86 Declaración de los Derechos del Hombre y del Ciudadano, art. 10.

87 Ibidem, art. 11.

88 Sobre esta cuestión, v. GómEz-Reino Y CARNOTA, Aproximación histórica al derecho de la imprenta y de la prensa en España (1480-1966), Madrid, 1977. 
Papa Pío IX promulga la Encíclica Quanta Cura y el Syllabus, en los que se condenan los errores de las doctrinas modernistas y, entre ellas, la siguiente proposición: que "es falso que la libertad civil para cualquier culto e igualmente la amplia facultad a todos concedida de manifestar clara y públicamente cualquier opinión y cualquier pensamiento, conduzcan a corromper más fácilmente las costumbre y espíritu de los pueblos y a propagar la peste del indiferentismo" 89 .

La condena pontificia de la libertad de cultos y de la libertad de pensamiento producirá una gran confusión y graves dilemas de conciencia entre los liberales católicos, pero servirá a los moderados para endurecer su política represiva contra la libertad de imprenta. Castelar publica un artículo, bajo el título "¿De quién es el Patrimonio Real? ${ }^{90}$, en el que critica la venta de algunos bienes del Patrimonio Real para sanear la Hacienda Pública, pero resarciendo a la Reina con una compensación económica. Castelar se pregunta si: "después de todo ¿ha dado la intendencia de Palacio algo que sea suyo? Esa es la cuestión. El Patrimonio Real es patrimonio de la nación, exclusivamente de la nación" y, añade, "no podemos comprender cómo se dice en este momento que la reina cede generosamente al país su propio patrimonion.

La ausencia de garantías jurídicas para el ejercicio de la libertad de expresión da lugar a la instrucción de un proceso penal a Castelar y a la expulsión de su cátedra de la Universidad. Ríos Rosas dirá en el Congreso que "las materias opinables no caen bajo la mano del Gobierno, y cuando en estas materias el Gobierno tacha a un filósofo o escritor de panteísta o ateo, comete una gravísima falta e infringe el derecho" ${ }^{91}$. A pesar del debate abierto, el Gobierno de Narváez incrementará las restricciones a las libertades públicas, utilizando a un singular personaje, el ministro Orovio, para llevar a cabo esta tarea, llegando a prohibir que los profesores pudieran pertenecer a partidos políticos y a prohibir cualquier publicación de doctrinas erróneas religiosas, morales o políticas» ${ }^{92}$.

No debe sorprender, por tanto, que el Manifiesto del Gobierno Provisional, surgido de la Revolución del 68, se apresure a reafirmar

89 Syllabus, n. 49.

90 La Democracia, 21 de febrero de 1865.

91 Extracto de la Sesión del Congreso del día 28 de abril de 1865 (Gaceta de Madrid, 29 de abril de 1865).

92 Real Decreto de 22 de enero de 1867, arts. 8, 19 y 43. 
las libertades públicas y, en primer lugar, la libertad religiosa y de enseñanza. Añadiendo, a continuación, que «como natural resultado de la libertad religiosa y de la enseñanza, la revolución ha proclamado también la libertad de imprenta, sin la cual aquellas conquistas no serian más que fórmulas ilusorias y vanas" ${ }^{93}$. Las circunstancias antecedentes y las manifestaciones posteriores hacen que la Constitución de 1869 no se limite a proclamar la libertad de expresión, haciendo especial hincapié en la libertad de imprenta, sino que adopte garantías jurídicas efectivas para que su reconocimiento no se convierta en mera declaración fácilmente vulnerable por el Gobierno ${ }^{94}$.

La primera medida garantista es el reconocimiento de la libertad de expresión, sin remisión a ninguna ley. Al afirmar que nadie será privado del derecho a emitir libremente sus ideas u opiniones, no autoriza ni al legislador ni al gobierno a limitar y menos suprimir ese derecho. Lo dispuesto en la Constitución es suficiente para el reconocimiento y el ejercicio de la libertad de expresión. Únicamente, de manera excepcional, podrá suspenderse este derecho «temporalmente y por medio de una ley, cuando así lo exija la seguridad del Estado en circunstancias extraordinarias» ${ }^{95}$.

En el contenido del artículo 17 llama la atención la ausencia de la libertad de enseñanza, en su sentido más amplio, y de la libertad de cátedra, puesto que, en el Manifiesto del Gobierno Provisional, constituía un precedente claro de la libertad de expresión e imprenta. La libertad de enseñanza, limitada a la libertad de creación de centros, se traslada al artículo 24, que encabeza una serie de libertades de empresa, industria o profesión. Sin embargo, son acogidos en el artículo 17 los derechos de asociación y reunión, reconocidos por primera vez en el ordenamiento constitucional español como «perennes fuentes de actividad y progreso, que tanto han contribuido en el orden político y económico al engrandecimiento de otros pueblos, han sido

93 Manifiesto del Gobierno Provisional de 25 de octubre de 1868.

94 A pesar de la declaración de intenciones del Gobierno y del reconocimiento constitucional, las libertades individuales $y$, en concreto, la libertad de expresión continuaron siendo un problema para los sucesivos Gobiernos, tal vez acostumbrados a evitar los "abusos" de una manera contundente desde el el propio Gobierno. Carmen Servan recuerda las palabras de Sagasta «jcuántas veces, en caso tan doloroso, me pesaban esos derechos individuales como una losa de plomo! ("Como losa de plomo: El derecho a la libre emisión del pensamiento en el constitucionalismo de 1869", en Constitución en España: origenes y destinos, Centro de Estudios Políticos y Constitucionales, Madrid, 1998).

95 Constitución de 1869, art. 31. 
asimismo reconocidas como dogmas fundamentales por la revolución española» ${ }^{96}$.

El derecho de asociación se reconoce así, por primera vez en un texto constitucional, pasando de ser un hecho contemplado como peligroso y perseguible en la legislación precedente a un derecho natural e ilegislable, en la terminología de los constituyentes ${ }^{97}$. Aunque se considera un derecho ilegislable, la tradicional prevención frente al asociacionismo se deja traslucir en el régimen de garantías, mucho más debilitado que en los otros derechos. Así, se introduce como límite de este derecho "la moral pública», un concepto jurídico indeterminado que, si bien hoy figura como límite genérico de todos los derechos fundamentales, en el texto constitucional de 1869 es aplicable únicamente al derecho de asociación ${ }^{98}$. El establecimiento de este límite tiene, además, el componente especial de ser susceptible de interpretación de la moral pública como moral católica, dado el carácter confesional del Estado que, si bien no está formalizado en la propia Constitución, se deduce del Concordato de 1851 que, al no ser denunciado, se presume que continúa vigente en el derecho español posrevolucionario ${ }^{99}$.

Un nuevo punto débil, que puede advertirse en las garantías de este derecho, lo vamos a encontrar en el artículo 19, al atribuir a la autoridad gubernativa la facultad de suspender una asociación, siempre que usus miembros delinquieren por los medios que la misma les proporcione». Este motivo es suficiente para decretar la disolución, si bien no determina a qué autoridad corresponde dictar el acto disolutorio correspondiente. El texto constitucional dispone que los reos deberán ser sometidos al Juez competente, la autoridad gubernativa podrá suspenderla y se supone que del resultado del proceso $y$, al margen de las penas que pudieran aplicarse a sus miembros, correspon-

96 "Manifiesto del Gobierno Provisional", cit.

97 CAÑ̃ PALOP, J. R. del, "Evolución histórica del derecho de asociación en el constitucionalismo español», en Introducción a los derechos fundamentales, vol. I, cit., págs. 83 y ss.

98 Olías de Lima GeTE, B., La libertad de asociación en España (1868-1974), Madrid, 1977.

99 "Así, para la libertad de asociación, la puntualización de la Constitución para todos los fines que no sean contrarios a la moral pública, sirve para mantener en el Código Penal revisado una tipificación delictual de la actividad sindical proveniente de la época anterior, cuando no existía tal derecho. El Tribunal Supremo argumentará que es efectivamente contraria a la moral pública.La libertad, ni aun asi constitucionalmente declarada, sigue sin serlo por virtud inmediata de la Constitución para determinados sectores sociales" (CLAVERO, B., Manual de historia constitucional de España, Madrid, 1990, págs. 104-105). 
de al juez dictar, en su caso, la pena de disolución. Todo ello, sin embargo, es una cuestión interpretativa, porque el precepto constitucional adolece de mecanismos garantistas suficientemente claros para proteger, en este supuesto, el derecho de asociación. Finalmente, el constituyente se remite a la ley para proceder a la disolución de «toda asociación cuyo objeto o cuyos medios comprometan la seguridad del Estado". Recurre aquí el constituyente a un procedimiento que ha reprobado con carácter general, al eludir la remisión a la ley del régimen de ejercicio de un derecho, por su naturaleza ilegislable, según la terminología constituyente.

El artículo 17 reconoce, igualmente, el derecho de reunión, que carece de antecedentes en el derecho constitucional español, si bien, en el derecho comparado, ya había sido reconocido en la Primera Enmienda a la Constitución de los Estados Unidos (1791), en el artículo 7 de la Constitución francesa de 1793, así como en el artículo 19 de la Constitución belga de 1831 y en el artículo 8 de la Constitución francesa de 1848. El derecho de reunión padece, también, de un debilitamiento de las garantías jurídicas, respecto a las que han sido otorgadas a otras libertades públicas en la Constitución de 1869. Así, el artículo 18 dispone que: "Toda reunión pública estará sujeta a las disposiciones generales de la policía. Las reuniones al aire libre y las manifestaciones públicas sólo podrán celebrarse de día».

El régimen jurídico del ejercicio de este derecho ni siquiera se remite a las leyes de policía, como hace la Constitución belga de 1831, sino que se remite a un concepto genérico de disposiciones generales de policia, $y$, por tanto, admite la posibilidad de que el poder gubernativo ejerza facultades de regulación y limitación del ejercicio de este derecho, poco coherentes con los principios generales que han presidido la configuración constitucional de los derechos y libertades fundamentales.

Por lo que se refiere al derecho de petición, cabe decir que se trata de un derecho con notable tradición en el derecho constitucional precedente (art. 373 de la CE de 1812; art. 3 de la CE de 1837, art. 3 de la CE de 1845); no obstante, es la primera vez que se reconoce el derecho de petición colectivo, si bien se excluye de su disfrute a los miembros de las fuerzas armadas (art. 20), que, a nivel individual, sólo lo podrian ejercer "con arreglo a las leyes de su instituto en cuanto tenga relación con éste" (art. 20) ${ }^{100}$. 


\subsection{La libertad religiosa}

Al abordar, en el ámbito de las libertades públicas, el derecho dê libertad religiosa es necesario tener presente dos coordenadas fundamentales: a) el momento histórico; b) el Estado y la nación que pretende proclamarlos. Porque, en 1869, una fecha concreta, y en España, una nación con una larga historia, la libertad religiosa continuaba siendo la "gran desconocida".

A pesar de que la revolución americana y los primeros textos $y$ declaraciones de derechos y libertades situaron a la libertad religiosa a la cabeza de las libertades públicas y lo mismo fueron haciendo, de manera sucesiva, las Constituciones francesas y de otros países europeos, en España las Constituciones liberales ignoraron o no pudieron plasmar esta libertad en el elenco de las libertades públicas. Por el contrario, tomando como ejemplo la Constitución de 1812, se prohíbe expresamente esta libertad en aras de una declaración con pretensiones proféticas: "La Religión de la Nación española es y será perpetuamente la católica, apostólica y romana, única y verdadera. La Nación la protege por leyes sabias y justas, y prohibe el ejercicio de cualquier otra».

La unidad religiosa de la nación española es incompatible con la libertad de elección de las propias creencias religiosas, por lo que surge la incompatibilidad entre confesionalidad del Estado y libertad religiosa. Éste va a ser el debate que centrará las discusiones del artículo 21 de la Constitución de 1869. La Iglesia se volvió celosa defensora de la unión entre el Altar y el Trono, a partir de la conversión del cristianismo en religión oficial del Imperio Romano ${ }^{101}, y$, así, en fechas cercanas al período que estudiamos, el papa Gregorio XVI, al tiempo que condenaba la libertad de conciencia ${ }^{102}$ y la libertad de impren-

101 Souto PAZ, J. A., Comunidad política y libertad de creencias, cit., págs. 63 y ss.

102 «De esta cenagosa fuente del indiferentismo mana aquella absurda y errónea sentencia o, mejor dicho, locura, que afirma y defiende a toda costa y para todos, la libertad de conciencia. Este pestilente error se abre paso, escudado en la inmoderada libertad de opiniones que, para ruina de la sociedad religiosa y de la civil, se extiende cada día más por todas partes, llegando la imprudencia de algunos a asegurar que de ella se sigue gran provecho para la causa de la religión. ¡Y qué peor muerte para el alma que la libertad del error! Decía San Agustín ... en una palabra, la mayor y más mortífera peste para la sociedad, porque aun la más antigua experiencia enseña cómo los Estados, que más florecieron por la riqueza, poder y gloria, sucumbieron por el solo mal de una inmoderada libertad de opi- 
ta ${ }^{103}$, declaraba que: "Las mayores desgracias vendrían sobre la religión y sobre las naciones, si se cumplieran los deseos de quienes prevenden la separación de la Iglesia y el Estado, y que se rompiera la concordia entre el sacerdocio y el poder civil. Consta, en efecto, que los partidarios de una libertad desenfrenada se estremecen ante la concordia, que fue siempre tan favorable y tan saludable así para la religión como para los pueblos" ${ }^{104}$.

En fechas inmediatamente anteriores a la Revolución del 68, el pontificado romano volverá a insistir sobre los "errores modernos", $y$, en especial, sobre la "locura" de la libertad de conciencia y de cultos, asi como la libertad de expresión ${ }^{105}$, siendo condenadas explícitamente en el "Syllabus" las siguientes proposiciones: "No conviene ya, en nuestra época, que la Religión católica se mantenga como la única religión del Estado, excluyendo cualesquiera otros cultos ${ }^{106}$; "Por ello laudablemente en algunos paises católicos se ha establecido por ley que sea lícito a quienes allá emigren, ejercer públicamente su propio culto, cualesquiera que éste fuere" ${ }^{107}$; "En efecto, es falso que la libertad civil para cualquier culto, e igualmente la amplia facultad a todos concedida de manifestar clara y públicamente cualquier opinión y cualquier pensamiento, conduzcan a corromper más fácilmente las costumbres y el espíritu de los pueblos, y a propagar la peste del indiferentismon 108 . Igualmente, se condena expresamente la proposición: "Debe estar separada la Iglesia del Estado, y el Estado de la Iglesia»" ${ }^{109 .}$

nión, libertad en la oratoria y ansia de novedades" (Gregorio XVI, Mirari Vos, 15 de agosto 1832, sobre los errores modernos, 10 ).

103 «Debemos también tratar en este lugar de la libertad de imprenta, nunca suficientemente condenada, si por tal se entiende el derecho de dar a la luz pública toda clase de escritos; tibertad por muchos deseada y promovida... Colijan, por tanto, de la constante solicitud que mostró siempre esta Sede Apostólica en condenar los libros sospechosos y dañinos, arrancándolos de sus manos, cuán enteramente falsa, temeraria, injuriosa a la Santa Sede y fecunda en gravísimos males para el pueblo cristiano es la doctrina de quienes, no contentos con rechazar tal censura de libros como demasiado grave y onerosa, llegan al extremo de afirmar que se opone a los principios de la recta justicia, y niegan a la lglesia el derecho de decretarla y ejercitarla (ibidem, $n .11$ y 12).

104 lbidem, n.16.

105 Pío IX, Encíclica Quanta Cura (1864), n. 3.

106 N. 77.

107 N. 78.

108 N. 79.

109 Syllabus, n. ${ }^{\circ} 55$. Vid. POLO SABÁU, J. R., "La significación histórica en España del Concilio Vaticano II y el derecho de libertad religiosa", en Revista de la Facultad de Derecho de la Universidad Complutense de Madrid, n. ${ }^{\circ} 89,1998$, págs. 257 y ss. 
En la doctrina pontificia están estrechamente ligadas la separación Iglesia-Estado; la aconfesionalidad del Estado; la libertad religiosa y de cultos y las libertades de pensamiento y expresión. El debate constituyente va a reflejar esta oposición radical de la Iglesia, que se hará patente de manera especial a propósito del debate del artículo $21^{110}$. El nuevo régimen surgido de la Revolución del 68 no pretendía una ruptura con la jerarquía católica, a pesar de algunas actuaciones reprobables de los ministros de Gracia y Justicia y de Fomento; que serían rectificadas parcialmente por el propio Gobierno ${ }^{111}$. Por esta razón, el Presidente de las Cortes, Nicolás Maria Rivero, quiso exponer ante dos diputados eclesiásticos tan relevantes como García Cuesta, cardenal de Santiago ${ }^{112}$, y Antolín Monescillo, obispo de Jaén, la postura de la Comisión encargada de elaborar las bases de la nueva Constitución sobre el tema de la "cuestión religiosa»"13.

El Nuncio Franchi, en carta dirigida al Secretario de Estado de la Santa Sede, Antonelli, describe así esta primera entrevista: "El señor Rivero propuso en términos generales sus ideas sobre la separación Iglesia-Estado y el Cardenal de Santiago rechazó enérgicamente este divorcio como un absurdo y fuente de nuevas calamidades para España. Rechazó igualmente la tolerancia religiosa, sosteniendo la necesidad de conservar inalterada la unidad católica. Han sido aplazadas las discusiones, pero ambos prelados están dispuestos a combatir enér-

110 En el Proyecto de Constitución, la "cuestión religiosa" estaba centrada en los artículos 20 y 21 , que se refundirian después en uno sólo, que sería el aprobado artículo 21 .

111 Nos referimos a los Decretos dictados por el Ministro de Gracia y Justicia, suprimiendo la Compañía de Jesús; la prohibición de adquirir y poseer bienes a las comunidades religiosas; la supresión de monasterios, conventos, colegios, congregaciones y casas religiosas de ambos sexos, etc., dictados durante el año 1868. Sin derogar estas normas, el Gobierno rectificará esta política al reconocer el derecho de asociación y acoger en esta figura a las comunidades religiosas (vid. CÁRCEL ORTí, V., Iglesia y Revolución..., cit., págs. 146 y ss.).

112 Sobre la figura y personalidad de García Cuesta, v. Presas Barrosa, C., De García Cuesta a Guisasola Rodríguez (1862-1888), Santiago de Compostela, 1999. La autora recoge las intervenciones del Cardenal García Cuesta en las Cortes Constituyentes, publicadas en el Boletín Oficial Eclesiástico del Arzobispado de Santiago.

113 Utilizamos la expresión "cuestión religiosa» restringida al debate constituyente en el sentido propuesto por PETSCHEN: «la materia de los artículos 20 y 21 del Proyecto de Constitución, que iba a convertirse en la base fundamental para la actuación de los gobiernos en política religiosa» (/glesia-Estado..., cit., pág. 18). En el mismo sentido, CÁRCEL OrTí, V., Iglesia y Revolución en España (1868-1874), Pamplona, 1979, pág. 191). 
gicamente las ideas del Sr. Rivero, que desea la separación de la lglesia del Estado con el pretexto de querer restituir a la Iglesia su plena libertad $\mathrm{e}$ independencia» ${ }^{114}$.

En una segunda reunión, celebrada un día después, el Presidente de las Cortes propuso las siguientes cuestiones a ambos prelados:

1. ${ }^{\circ}$ Reconocimiento de la libertad de la Iglesia.

2..$^{\circ}$ Concesión a la Iglesia de todo el capital en renta consolidada de la dotación correspondiente, de acuerdo con el Concordato.

3. ${ }^{\circ}$ Renuncia del Estado al exequatur y a otras regalías, comprendido el mismo patronato, y que dejare, por consiguiente, libertad al Papa para los nombramientos de obispos y a éstos la colación canónica de todas las prebendas.

4..$^{\circ}$ La Iglesia no debería pedir al Estado otra protección que la debida a todos los ciudadanos, es decir, tutela del orden público y libre ejercicio de los principios proclamados en la Constitución ${ }^{115}$.

Aunque esta propuesta coincide sustancialmente con la doctrina aprobada por la Iglesia Católica, un siglo más tarde, en el Concilio Vaticano $\left.\right|^{116}$, sirviendo de base y fundamento a las relaciones entre

114 Cit. por CÁRCel ORTI, V., Iglesia y Revolución..., cit., pág. 188.

115 Ibidem, pág. 189.

116 "La Iglesia, que por razón de su misión y competencia, no se confunde en modo alguno con la comunidad política ni está atada a sistema político alguno... La comunidad política y la lglesia son independientes y autónomas, cada una en su propio terreno... Ciertamente, las realidades temporales y las realidades sobrenaturales están estrechamente unidas entre sí, y la misma lglesia se sirve de medios temporales en cuanto su propia misión lo exige. No pone, sin embargo, su esperanza en privilegios dados por el poder civil; más aún, renunciará al ejercicio de ciertos derechos legítimamente adquiridos tan pronto como conste que su uso puede empañar la pureza de su testimonio o las nuevas condiciones de vida exijan otra disposición" (Constitución Gaudium et Spes, n. 76). Por su parte, la Declaración Dignatatis Humanae, n. 2, dice: "Este Concilio Vaticano declara que la persona humana tiene derecho a la libertad religiosa. Esta libertad consiste en que todos los hombres han de esta inmunes de coacción, tanto por parte de personas particulares como de grupos sociales y de cualquier potestad humana, $y$ esto de tal manera, que en materia religiosa ni se obligue a nadie a obrar contra su conciencia ni se le impida que actúe conforme a ella en privado y en público, solo o asociado con otros, dentro de los límites debidos. Declara, además, que el dere- 
el Estado y la Iglesia, reflejadas en la Constitución de 1978 y en los Acuerdos con la Santa Sede, actualmente vigentes ${ }^{117}$, para el Nuncio Franchi, la propuesta del Presidente de las Cortes mereció el siguiente comentario: «En una palabra, el señor Rivero, bajo el falso pretexto de garantizar la libertad e independencia de la Iglesia, expuso netamente el absurdo principio de la separación Iglesia-Estado. El Cardenal de Santiago le repitió enérgicamente lo absurdo de dicho principio, condenado por la Iglesia, y las funestas consecuencias que su aplicación acarrearía en España tanto a la Iglesia como a la sociedad civil. Declaró igualmente que este principio será unánimemente combatido por todos los obispos. Quiso entonces el señor Rivero que los dos obispos se presentaran a la Comisión encargada de redactar las bases de la futura Constitución, que se hallaba reunida en aquellos momentos, declarando que en la futura Constitución debía mantenerse el principio de la unidad católica, con exclusión de cualquier otro culto, porque así lo exigian la santidad de la religión católica, las circunstancias de la nación española y el Concordato vigente. Rechazó igualmente el cardenal las objeciones del señor Olózaga sobre la pretendida reciprocidad, basada en la tolerancia, usada con los católicos en los países protestantes, porque no hay reciprocidad entre lo verdadero y lo falso; ...y, por último, con acento autoritario, invitó a los miembros de la Comisión a que reflexionasen seriamente sobre los peligros que correría España en el caso de que fuese proclamada la libertad de cultos y la grave responsabilidad que sobre ellos caía si exponian a la nación a nuevas y más funestas desgracias» ${ }^{118}$.

libertad religiosa está realmente fundado en la dignidad misma de la persona humana, tal como se la conoce por la palabra revelada de Dios y por la misma razón natural. Este derecho de la persona humana a la libertad religiosa ha de ser reconocido en el ordenamiento jurídico de la sociedad, de forma que llegue a convertirse en un derecho civil'".

117 El Acuerdo entre el Estado español y la Iglesia Católica de 1976, calificado como Acuerdo-marco de los posteriores Acuerdos firmados en 1979 entre ambas instituciones, declara, entre otras cosas, que: "Considerando que el Concilio Vaticano II, a su vez, estableció como principios fundamentales, a los que deben ajustarse las relaciones entre la comunidad política y la Iglesia, tanto la mutua independencia de ambas Partes, en su propio campo, cuanto una sana colaboración entre ellas; afirmó la libertad religiosa como derecho de la persona humana, derecho que debe ser reconocido en el ordenamiento jurídico de la sociedad; y enseñó que la libertad de la lglesia es el principio fundamental de las relaciones entre la Iglesia y los Poderes públicos y todo el orden civil...".

118 Carta del Nuncio de 18 de marzo de 1869, en CÁRCEL ORTí, V., Iglesia y Revolución..., cit., págs. 189-190. 
Las posturas de los diputados constituyentes oscilaban entre la separación Iglesia-Estado y la confesionalidad estatal y, por otra parte, el reconocimiento de la libertad religiosa o, al menos, de la tolerancia. Igualmente, la Comisión constitucional propuso un texto, que sometió a la consideración de los diputados eclesiásticos, y que contenía las siguientes fórmulas: 1) Confesionalidad católica del Estado; 2) subvención estatal del culto y clero, y 3) libertad religiosa para extranjeros y españoles que profesaren otras creencias religiosas. Los obispos rechazaron, igualmente, esta propuesta.

El texto que la Comisión propuso como definitivo y que resultaria, finalmente, aprobado, no hace una referencia expresa a la confesionalidad estatal, pero tampoco la rechaza; por este motivo, la fórmula "La Nación se obliga a mantener el culto y los ministros de la Religión católica" tiene un significado implícito de confesionalidad católica, única confesión subvencionada por el Estado, y que no se opone a la confesionalidad garantizada en el Concordato, por lo que se debe entender que dicha declaración persiste al no ser denunciada, ni contradicha ${ }^{119}$.

Rechazada la separación Iglesia-Estado, y cualquier fórmula de aconfesionalidad, el reconocimiento de la libertad religiosa se realiza bajo una fórmula que refleja más el principio de reciprocidad y tolerancia para los extranjeros, a que hacía referencia Olózaga, que a un derecho de libertad religiosa. Sólo así se puede entender que este derecho se reconozca, en primer lugar, a los extranjeros residentes en España y, en un segundo término, en el caso al parecer insólito de que, "si hubiere algún español que no fuere católico", se extiende este derecho a esos españoles disidentes de la religión nacional.

119 De opinión contraria es el Nuncio Franchi que manifiesta que con esta redacción use viola por completo el artículo primero del Concordato de 1851, donde se decia que la religión católica, apostólica y romana continúa siendo la religión de la Nación española con exclusión de cualquier otro culto». El texto constitucional no parece violar "por completo" el texto concordatario, porque nada se dice acerca de la confesionalidad del Estado, por lo que, en este caso, el silencio parece tener un significado positivo, acorde con el sentir de la Comisión. La duda podría surgir en relación con el último párrafo, "con exclusión de cualquier otro culto", pero si se tiene en cuenta que el texto concordatario habla de la Nación española, no parece que le afecte el hecho de que algunos extranjeros o españoles, a título individual, profesen otros cultos. 


\section{Libertades políticas y civiles}

Los artículos 24 al 27 reconocen una serie de libertades referidas a la condición del ciudadano como "homo faber» y con claro contenido socioeconómico. Se reconoce la libertad de empresa y profesión y la libertad de enseñanza o de creación de establecimientos docentes. Junto a estas libertades se reconocen otras de carácter político como el derecho de sufragio universal y la libertad de acceso a las funciones públicas. Habría que incluir aquí el derecho a la propiedad, que no se reconoce positivamente en la Constitución del 69, sino negativamente, al establecer la prohibición de la privación temporal o perpetua de los bienes y derechos y de la expropiación, salvo en virtud de sentencia o mandamiento judicial respectivamente (arts. 13 y 14).

La Constitución del 69 sigue otros precedentes constitucionales al no realizar un reconocimiento expreso del derecho de propiedad. Salvo en la Constitución del 12, en la que hace una formulación positiva del derecho de propiedad, que ha sido uno de los pilares de las Declaraciones de Derechos de la Revolución liberal, junto a la vida y a la libertad, en las demás constituciones se da por supuesto, limitándose a formular dos prohibiciones generales: la confiscación de bienes y la privación de la propiedad ${ }^{120}$. El derecho a la propiedad representa, en el contexto liberal, la libertad económica y la seguridad de la subsistencia vital. Desde esa perspectiva, el derecho a la propiedad encabezaría las otras libertades enunciadas en la Constitución: la libertad de industria, de profesión, de acceso a la función pública, libertades encaminadas a realizar una actividad profesional y garantizar la subsistencia económica.

Resulta extraño, también, que se enumere entre estas libertades, la libertad de enseñanza, entendida en su significación más estricta como libertad de creación de centros docentes, es decir, como libertad de empresa, omitiendo cualquier referencia a la libertad de cátedra, que había sido una de las banderas de la Revolución y del Manifiesto del Gobierno Provisional. La libertad de cátedra parece reconducirse a la libertad de pensamiento, garantizada en el artículo 17, mientras que el derecho de creación de establecimientos docentes se presenta como una manifestación de la libertad de empresa, que se puede ejercer sin previa licencia, "salvo la inspección de la Autoridad competente por razones de higiene y moralidad" (art. 24). 
4.1. Entre las libertades políticas destaca sobre todas el reconocimiento del sufragio universal, garantizado en el artículo 16: "Ningún español que se halle en el pleno goce de sus derechos civiles podrá ser privado del derecho de votar en las elecciones de Senadores, Diputados a Cortes, Diputados provinciales y Concejales». En realidad, el sufragio universal constituye uno de los principios fundamentales de la Revolución, de tal manera que ya en el Manifiesto "España con honra», proclamado en Cádiz el 19 de septiembre de 1868 , que pone en marcha el proceso revolucionario, se declara que: "Queremos que un Gobierno Provisional que represente todas las fuerzas vivas del país asegure el orden, en tanto que el sufragio universal echa los cimientos de nuestra regeneración social y política».

El Manifiesto del Gobierno Provisional de 25 de octubre de 1868 declara que: "Destruido el obstáculo (la monarquía borbónica) y expedito el camino, la revolución ha establecido el sufragio universal, como la demostración más evidente y palpable de la soberanía del pueblo...". Anticipándose a la propia Constitución, el Gobierno Provisional reconocerá el sufragio universal el 9 de noviembre de 1868: "Cuando la soberanía nacional es la única fuente de donde se han de derivar todos los poderes y todas las instituciones de un país, el asegurar la libertad más absoluta del sufragio universal, que es su legítima expresión y su consecuencia indeclinable, constituye el deber más alto y de más inflexible responsabilidad para los Gobiernos que, brotando de esa misma soberanía en los primeros instantes de la Revolución, son los depositarios de la voluntad nacional".

En el debate constituyente, entre otros diputados, se opuso al reconocimiento del sufragio universal Cánovas del Castillo. Aprovechando que el texto limitaba el ejercicio del derecho de voto a aqueIlos ciudadanos que se hallaban "en el pleno goce de los derechos civiles", manifiesta su sorpresa ante el hecho de que el sufragio universal esté comprendido entre los derechos individuales y naturales. «Esos derechos - argumenta Cánovas - que realmente se derivan sólo de la naturaleza, no podéis negarlos a ningún ser humano. Basta existir para poseerlos en estado de plenitud o en su estado de germen, pero para poseerlos de todos modos. Y bien señores ¿es que no existe la mujer?, ¿es que no vive en ella la conciencia humana? Nadie lo duda ciertamente» 121 .

121 Diario de Sesiones de las Cortes Constituyentes, sesión de 8 de abril de 1869. 
Cánovas denuncia la ausencia del derecho de sufragio femenino - auténtico talón de Aquiles de la Constitución del 69-, pero no con la intención de reivindicarlo, sino más bien como un argumento para destituir al sufragio universal de su carácter de derecho natural. "Lo que hay - añade Cánovas - es que, a pesar de lo que dice el Proyecto de Constitución, o más bien, de lo que queréis que diga, vosotros reconocéis implícitamente al excluir de esta función a la mujer, que en el derecho electoral, hay y no puede menos de haber, fundamental y esencialmente, condiciones de capacidad. Suprimir estas condiciones de capacidad, y tendréis que conceder de cualquier manera a la mujer el derecho electoral. Es necesaria cierta capacidad que no admitís en la mujer por razón de su sexo, y por eso se lo negáis" 122 .

Sentado el principio de la necesaria capacidad para el ejercicio del derecho electoral, Cánovas plantea la inviabilidad del carácter universal del sufragio. Así, agrega, que: «Una vez admitido que la capacidad es una condición necesaria para el disfrute del derecho electoral, ¿no cabe pensar que pudiera haber otras incapacidades esenciales que debieran privar del ejercicio de este derecho, tan graves por lo menos como la diferencia de sexo en las mujeres? Pues qué, ¿es tan claro, como consigna este artículo del proyecto de Constitución, es tan claro que tenga derecho a votar los impuestos que pesan sobre los demás el que no contribuye a ellos con una mínima parte siquiera?»123. Es evidente que Cánovas pretende atacar el sufragio universal y defender el tradicional sufragio censitario. No obstante, queda en entredicho el carácter universal de un sufragio del que están excluidas las mujeres, aunque ello fuera una norma común en el derecho comparado contemporáneo.

4.2. La libertad de acceso a los empleos y cargos públicos se convierte en un derecho constitucional de los españoles, que debe estar presidido por los principios de mérito y capacidad (art. 27). Estos principios figuran ya en las Constituciones de 1837 y 1845 y están encaminadas a eliminar el arbitrismo y el favoritismo en la

122 Ibidem.

123 Ibidem. Comentando esta intervención de Cánovas, SÁNCHEZ AgESTA manifiesta que "aún hoy nos seduce por el vigor y la claridad de sus argumentos: Podría quizá, con el de Donoso sobre la Dictadura y el de Castelar sobre la tolerancia, ocupar puesto preferente en una antología de discursos políticos del siglo XIX" (Historia del Constitucionalismo..., cit., pág. 299). 
selección de los funcionarios. La trasposición de esta norma constitucional a la praxis administrativa, sin embargo, ha demostrado ser difícil y escasamente eficaz. Las descripciones de las cesantías y de las provisiones de los cargos públicos a lo largo de todo el siglo XIX reflejan un estado de cosas bastante alejado de las prescripciones constitucionales.

Resulta original la mención constitucional de la no discriminación por motivos religiosos para el desempeño de empleos públicos, así como para la adquisición y el ejercicio de derechos civiles y políticos. Lo que resulta original $y$, al mismo tiempo, extraño es que la prohibición de discriminación se limite a la profesión religiosa, sin mencionar ninguna otra causa de no discriminación. La razón, sin embargo, se encuentra en lo dispuesto en el artículo 21. El reconocimiento de la libertad religiosa exige, por coherencia, que para el desempeño de empleos y cargos públicos no se exija la condición de católico, requisito que se derivaba, en el derecho precedente, del carácter confesional del Estado y de la prohibición de la práctica de cualquier otro culto. La inclusión de esta cláusula de no discriminación se debe a la enmienda presentada por el diputado Montesinos al artículo 21. Aunque la enmienda fue rechazada en relación con el referido artículo, fue trasladada al artículo 27 , satisfaciendo así las pretensiones del diputado enmendante $y$ el difícil equilibrio existente entre los grupos políticos integrantes de la Comisión constitucional, que, por otra parte, apoyaban al Gobierno.

4.3. La libertad de empresa y profesión está reconocida en el artículo 25 de la Constitución. Presenta la singularidad de reconocer este derecho a los extranjeros, lo que supone implícitamente que gozan también de este derecho los españoles: "Todo extranjero podrá establecerse libremente en territorio español, ejercer en él su industria, o dedicarse a cualquier profesión para cuyo desempeño no exijan las leyes títulos de aptitud expedidos por Autoridades españolas". La amplitud de este derecho reconocido a los extranjeros parece un reconocimiento explícito de la libertad de trabajo; sin embargo, la Comisión rechazó una enmienda en la que se proponía el reconocimiento expreso y con carácter general de la libertad de comercio, trabajo e industria para todo español y extranjero ${ }^{124}$. Aparte del hecho de que el precepto reconozca un derecho que no reconoce expresamente a los españoles, hay que advertir que la libertad de empresa

124 Vid. Carro Martínez, A., op. cit., pág. 238. 
y trabajo reconocida a los extranjeros tiene una serie de limitaciones expresamente reconocidas en la Constitución:

1) La exclusión del desempeño de cargo alguno que tenga aneja autoridad o jurisdicción, siempre que no estuviere naturalizado (art. 27).

2) La exclusión del derecho a fundar y mantener establecimientos de instrucción o de educación sin previa licencia, derecho reservado a los españoles (art. 24):

3) La necesidad de estar en posesión de los correspondientes títulos de aptitud expedidos por las Autoridades españolas, cuando así lo requieran las leyes para el ejercicio de una determinada actividad (art. 25).

4.4. La libertad de enseñanza aparece regulada de una forma ciertamente limitada, al reducirla al derecho, reconocido exclusivamente a los españoles, de fundar y mantener establecimientos de instrucción o de educación sin previa licencia, salva la inspección de la Autoridad competente por razones de higiene y moralidad (art. 24). Este artículo refleja el ideal del liberalismo originario en materia de educación, retomado ahora por los progresistas. El Decreto de 14 de octubre de 1868 sobre enseñanza, dictado por el ministro de Fomento, Ruiz Zorrilla, declara en su Preámbulo, que "la supresión de la enseñanza pública es, por consiguiente, el ideal al que debemos aproximarnos, haciendo posible su realización en un porvenir no lejano". Este pensamiento inspira el texto de la Constitución, al reconocer una libertad total de creación de centros de enseñanza por parte de la iniciativa privada, sin control por parte del Estado de la actividad académica (planes de estudios, idoneidad del profesorado, homologación de los títulos académicos, etc.). Como contraste a esta amplia libertad de enseñanza, la Constitución no dedica ni un solo precepto a la instrucción pública, que sí mereció la atención de los constituyentes de 1812 que dedicaron un Título íntegro a la Instrucción Pública. En cualquier caso, resulta sorprendente que, tampoco, se haga mención de la libertad de cátedra, porque, a pesar de su silencio, la Constitución no suprime la enseñanza pública y ha sido ahí donde se conculcó de manera insistente este derecho, como tuvimos ocasión de exponer anteriormente ${ }^{125}$. 


\section{Un numerus apertus de libertades públicas}

Como tuvimos ocasión de exponer al comienzo de este estudio, la Constitución de 1869 constituye el momento estelar del liberalismo español. La proclamación de la libertad, como un objetivo prioritario desde los orígenes del liberalismo, supera los obstáculos, las cautelas y las prevenciones de propios y extraños y procede a concretar la vigencia y efectividad de la libertad, a través del reconocimiento de libertades concretas, de libertades especializadas, de aspectos de la libertad que habían sido vulnerados o ignorados por los gobiernos de turno. El elenco de libertades reconocidas en el texto constitucional es, como hemos dicho anteriormente, el más amplio del constitucionalismo español del siglo XIX. Esto, sin embargo, no pareció suficiente a los constituyentes que introdujeron una nueva cláusula, que dice asi: "La enumeración de los derechos consignados en este título no implica la prohibición de cualquiera otro no consignado expresamente" (art. 29). El precepto constitucional advierte, asi, que el catálogo de libertades no agota la libertad, en su dimensión más plena. Asume, así, el viejo principio liberal: "Todo lo que no está prohibido está permitido", superando el principio minimalista, que pretende imponer que "sólo está permitido aquello que está expresamente reconocido". La Constitución de 1869, en definitiva, no sólo reconoce un amplio elenco de libertades, sino que establece como principio general la libertad individual y colectiva, que sólo podrá ser limitada en los casos previstos en la propia Constitución. 